تدريبات مقترحة لتنمية مهارات أداء السينكوب "Syncope" على آلة القانون

الباحث / محمد مصطفى سيد"

$$
\text { أ.دأد/ أمل جمال الدين محمد عياد }
$$

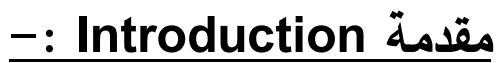

تعد الإيقاعات والضروب المختلفة عنصرا هام من عناصر الموسيقى العربية وتميزها دون غيرها من أنواع الموسيقى الأخرى ويرى الباحث أن الضروب الإيقاعية تعتبر إحدى أهم أسباب ظهور الكثير من الجمل اللحنية التى تحتوى إيقاعاتها على سينكوب فدائما هناك علاقة قوية بين الإيقاعات الداخلية للحن والضرب المصاحب خاصة فى الغناء العربي نظرا لإرتباط الإيقاعات بالتقطيع العروضى للكلمات مما يفرض على عازف القانون أن يراعى الدقة فى مصاحبة الغناء .

وعادة يمثل أداء السينكوب صعوبة لاى الطالب نظرا لاضطراب زمن الوحدة المنتظمة و انتقال النبر القوى من مكانه الأصلى إلى مكان الضغط الضعيف عن طريق وجود إطآلة الزمن بإستخدام الرباط الزمنى حيث يتطلب الأداء الجيد إدراك كامل للإيقاع والكثير من التدريب على الآلة فى أشكاله المتعدده وفى هذا البحث سيتم أقتراح تدريبات تكنيكية مختلفة تساعد على تتمية مهارات أداء السينكوب على آلة القانون

Research problem-: مثكلة البحث لاحظ الباحث عند تدريسه لآلة القانون صعوبة أداء السينكوب للى بعض طلاب آلة القانون سواء فى المقطوعات الآلية والغنائية مما يؤثر سلبا على الطالب فى تلبية متطلبات سوق العمل . Research Objectives - : أهداف البحث البه - إقتراح بعض التدريبات التكنيكية التى تساعد على تتمية مهارات أداء السينكوب على آلة القانون . أهمية البحث:أست بتحقيق الأهداف السابقة يمكن رفع كفاءة مهارات أداء السينكوب عند عازفي آلة القانون ومن ثم البه

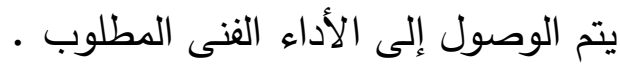


Questions of the research-: أسئلة البحث

ما هى التتريبات التكنيكية المقترحة التى تساعد على تتمية مهارات أداء السينكوب على آلة القانون?

Research limitations-: حدود البحث - اللوحة الإيقاعية ثنائية التقسيم • - - بعض مهارات العزف على آلة القانون . إجراء ات البحث:

Research Methodology : منهج البحث يعتد هذا البحث على المنهج الوصفى ( تحليل محتوى ). : The sample of the research : عينة البحث هن - بعض أثكال السينكوب المختلفة للوحة اللإيقاعية ثنائية التقسيم .

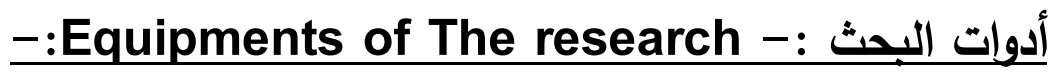

$$
\text { - }
$$

- بعض المواقع الموسيقية الموجودة على شبكة المعلومات الدولية .

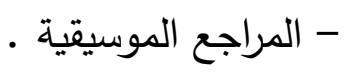

\section{مصطحات البحث :- Technical terms}

- التقنيات Technique -

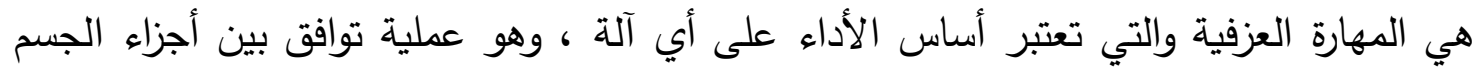

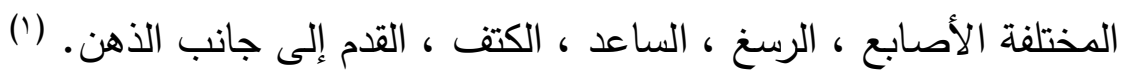
السينكوب Syncope

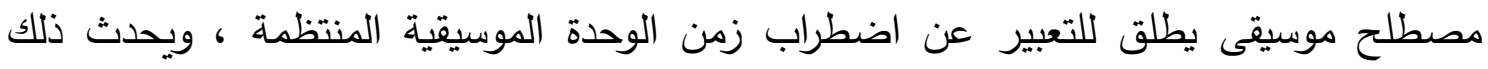

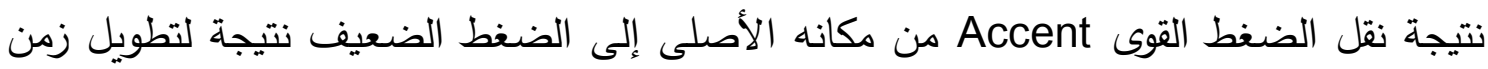

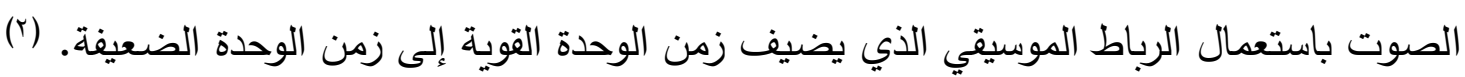

(1) Apel, Willi: Harvard Dictionary of Music, London Heimmann Educational Book's LTD, 1971.p733

(2) Sadie, Stanley: The New Grove Dictionary of Music And Musicians, vol24, Oxford University Press, New York, 2001. P 850

مجلة علوم وفنون الموسيقى - كلية التربية الموسيقية - المجلد الخامس والأربعون - يوليو اب.rم 


\section{الارباسات السابقة :}

الإراسة الأولى بعنوان :- الاسياته :

تمرينات مقترحة لتنمية مهارات أداء السينكوب ( syncope ) لاى الطالب المعلم مستنبطة

\section{من موسيقى لعبة ( سوبر ماريو ) (1)}

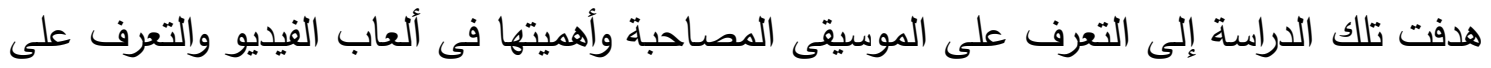

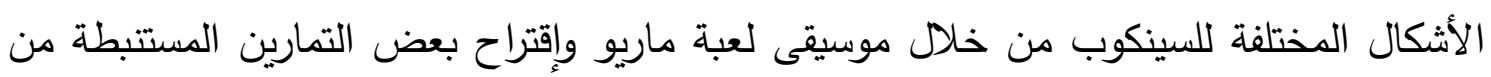

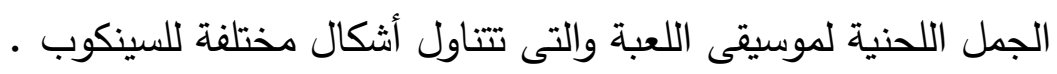

إتنقت الدراسة مع الدراسة الحالية فى تناول المنهج الوصفى وفى وضع التمارين التكنيكية وإختلف

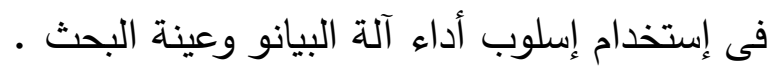

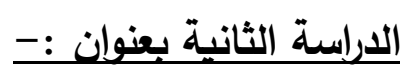

تدريبات مبتكرة لآلة القانون لأداء موسيقى العلزونة تأليف نبيل شورة ()

هدفت تلك الدراسة إلى التعرف على التراكيب النغفية والإيقاعية لمقطوعة جديدة من تأليف نبيل شورة ووضع تدريبات مبتكرة لآلة القانون للتغلب على المشاكل العزفية الخاصة بالمؤلفة المختارة

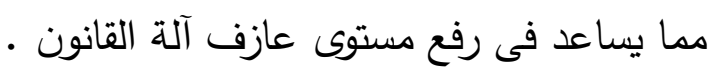

إتنقت الدراسة مع الدراسة الحالية فى تناول المنهج الوصفى وفى وضع التمارين التكنيكية وتتخللها بعض انواع السينكوب واختلفت فى عدم استخدام مؤلفة نبيل شورة وعدم وضع منهجية لكيفية التدريب على بعض أشكال السينكوب على آلة القانون.

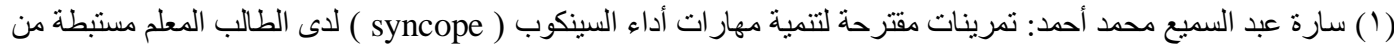

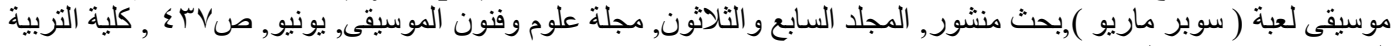

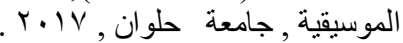

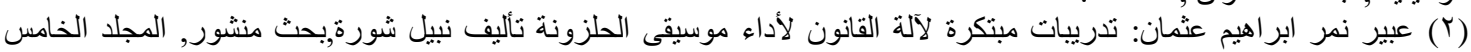

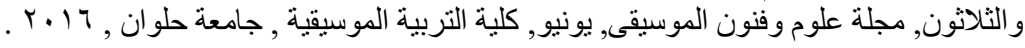


فعالية ورشة عمل لتذليل عض الصعوبات الإيقاعية فى مدونات المقررات العزفية (1)

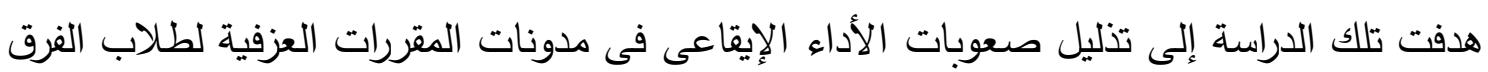

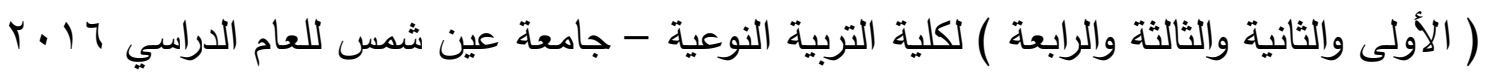
.r. IV إتنقت وضع التمارين التكنيكية وتتخللها بعض انواع السينكوب وإختلفت فى المنهج المستخدم وفى لإنى التطرق لآلة البيانو. ينقسم هذا البحث إلى جزئين :

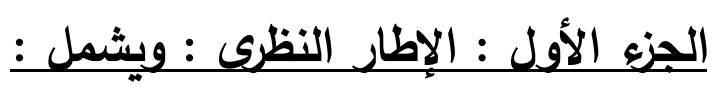
- أولا : بعض المهارات العزفية المستخدمة فى أداء السينكوب على آلة القانون. - ثانيا : الإيقاع ومفهومه فى الموسيقى العربية. الجزء الثانى : الإطار التطبيقى : التيق - أولا : معايير إعداد التدريبات المقترحة - ثانيا : تدريبات مقترحة لبعض أثكال السينكوب الناتجة بإختلاف القيمة الزمنية لها

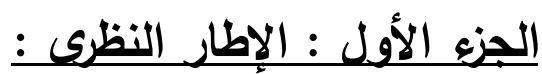
أولا : بعض المهارات العزفية المستخدمة فى أداء السينكوب على آلة القانون :

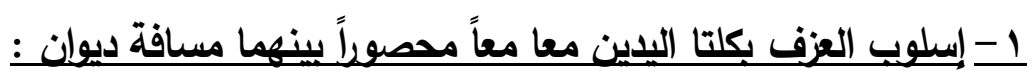
العزف باليدين معاً على ديوانين بسبابة اليد اليمنى 2R وسبابة اليد اليسرى 2L تكون حركتا

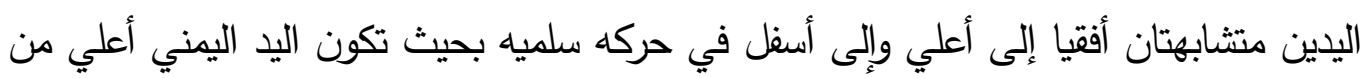
اليد اليسري بمسافه أوكتاف ويرمز لها بالر 8.

\footnotetext{
(1) مرام جلال توفيق زكى: فاعلية ورشة عمل لتنليل بعض الصعوبات الإيقاعية فى مدونات المقررات العزفية,بحث منشور, المجلد

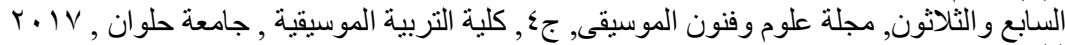

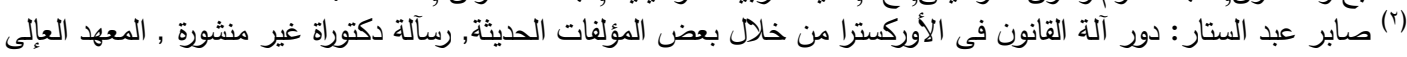

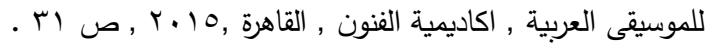




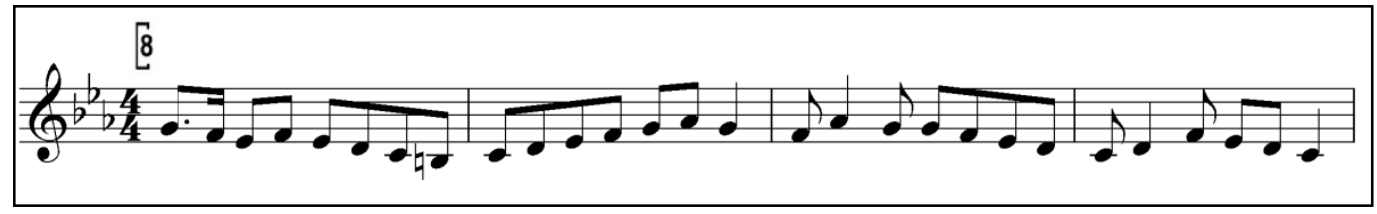

شكل رقم ا ( نموذج لأسلوب العزف بكلتا اليدين معا )

\section{ب ب الفرداج ( النغمة المتصلة ) :}

عزف النغمات بشكل متصل للأشكال الإيقاعية العريضة ومنها ( o - ل - - • ) على ديوانين

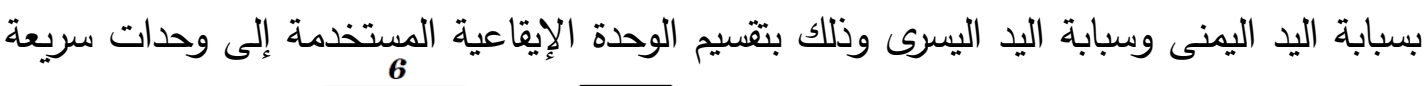

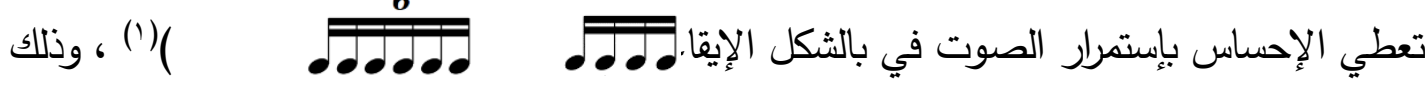
بتعاقب سبابة اليد اليمنى واليد اليسرى مع تركيز العازف على حساب الثنكل الإنيقاعي العريض الإهل

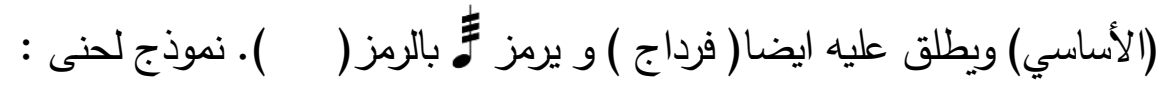

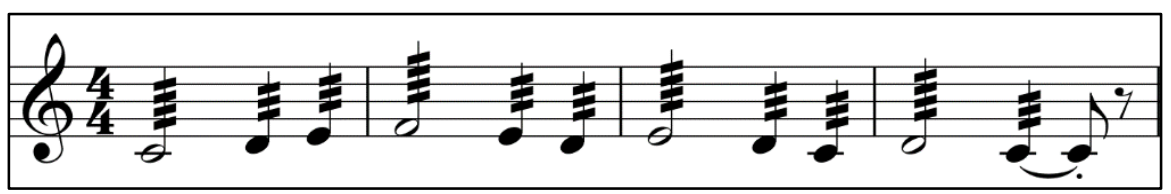

شكل رقم ץ ( نموذج لمهارة الفرداج )

- ثانيا : الإيقاع ومفهومه فى الموسيقى العربية :

- مفهوم الإيقاع بصفه عامة :

تشتق كلمة الإيقاع في اللغات الأوروبية من لفظ يونانى وهو مشتق من فعل بمعنى ينساب أو يتدفق، وفى اللغة العربية لفظ الإيقاع مشتق من التوقيع وهو نوع من المشية السريعة ومن المعروف ان مشية

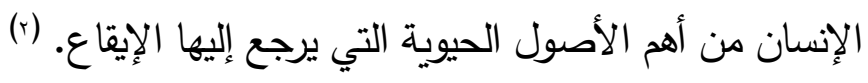

ومفهوم الإيقاع فى الموسيقى العربية بصفة عامة انهكل ما يتعلق بالثق الزمنى للصوت الموسيقى، وأن تتظيم الأصوات الموسيقية المكونة لأي لحن يقوم على وحدات زمنية متساوية وقد تتقسم بدورها إلى أجزاء متساوية أو مختلفة النسب في الطول والقصر . (')

(1) إيمان حسين عبد الحميد جنيد : برنامج مقترح لتذليل صعوبات أداء المؤلفات المعاصرة ذات المستوى الفني المتقدم لآلة القانون ,

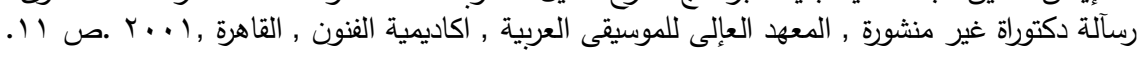

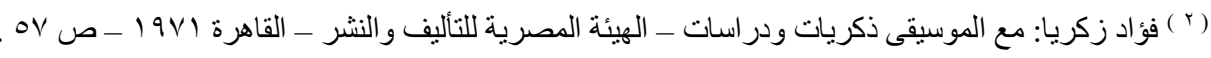

مجلة علوم وفنون الموسيقى - كلية التربية الموسيقية - المجلد الخامس والأربعون - يوليو اب.rم 
والإيقاع بمفهومه السابق يتكون من ست عناصر هي:

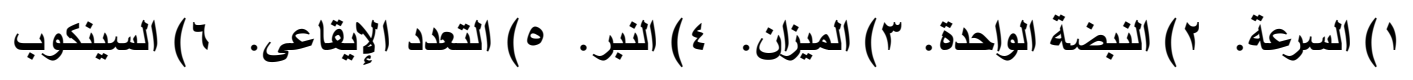

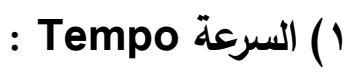

وهي من أهم عناصر الإيقاع وهي تستخدم بوجه عام التثير إلى السرعة التى يجب أن يؤدى بها العازف

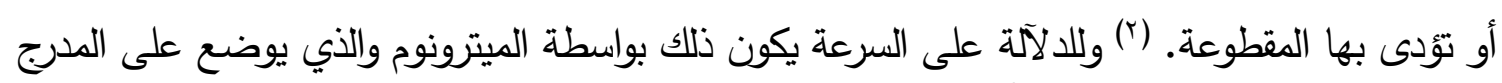

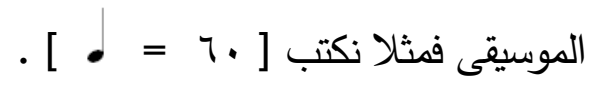

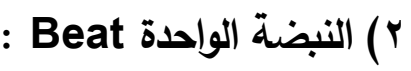

هو النبض الأساسي الذي تتضمنه الموسيقى المقننة، وبالتالى هى الوحدة التى يعد ( أو يحسب ) بها

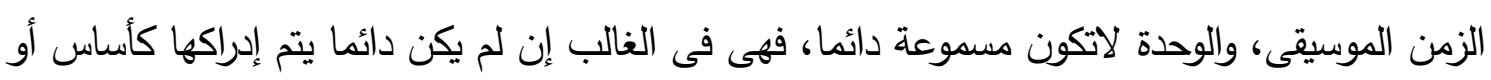

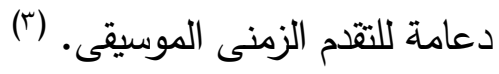

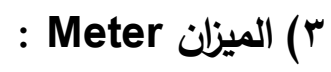

يتم التعبير عن الميزان بعدد الوحدات لقيمة زمنية معينة تظهر فى كل مازورة ولتحديد عدد أزمنة المازورة يوضع رقمان أحدها يعلو الأخر فى صورة بسط ومقام فى أول المقطوعة الموسيقية بعد المفتاح

والدليل. (₹)

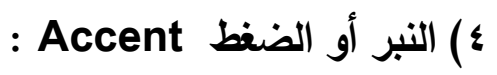

كلمة أصلها لاتينى ومعناها إختلاف درجات الضغط في أداء القطعة الموسيقية، ويعد النبر هو أحد

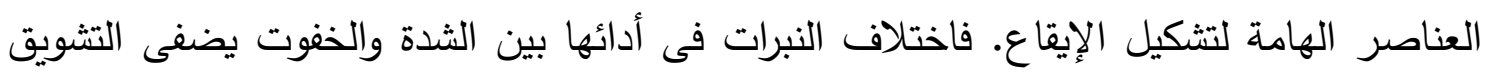
والحيوية للحركة الإيقاعية للنغمات, وتفقد الموسيقى حيويتها إذا سارت المقطوعة الموسيقية بطولها

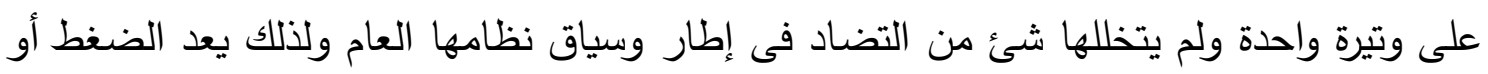

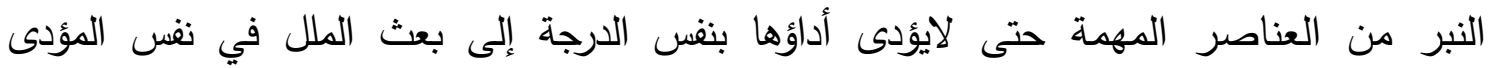

والمستمع.(0)

(ال) وينى شاكر، اميمة أمين: كتاب المعلم فى الإيقاع الحركى والألعاب الموسيقية - الجزء الأول - وزارة التربية والتعليم - مطابع

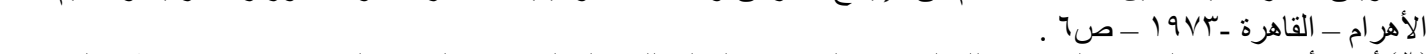

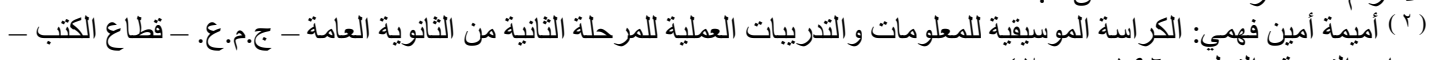

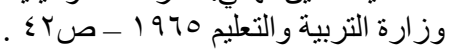

(3) Barry Kernfeld: The New Groves Dictionary of Jazz - Vol. 1 - USA - 1988 - P 85.

(4) Cooper Grosvwpenor, Mayer, Leonard: The Rhythmic Structure of Music - Chicago University - USA $1963-\mathrm{P} 3$.

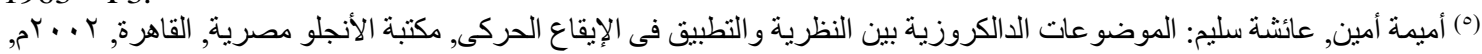




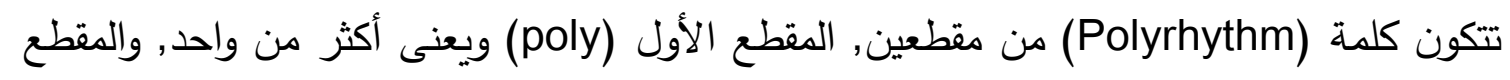

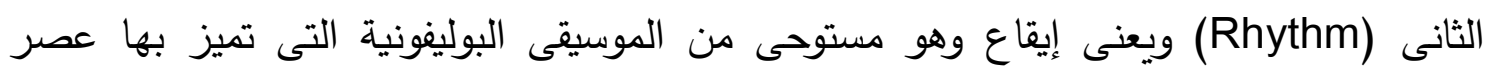
الباروك.

\section{(السينكوب Syncope}

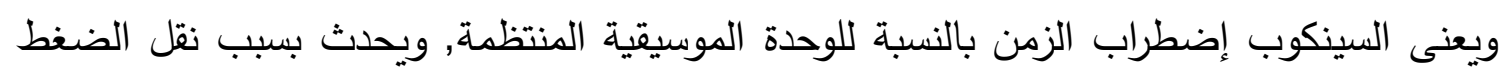

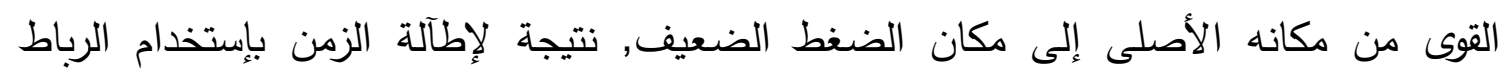

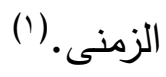

- - مفهوم الإيقاع في الموسيقى العربية :

هو الضرب أو الإيقاع المصاحب للحن وهو عنصر هام جدا يلي اللحن فى الأهية حيث يعطى

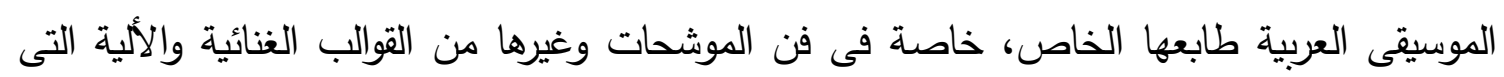

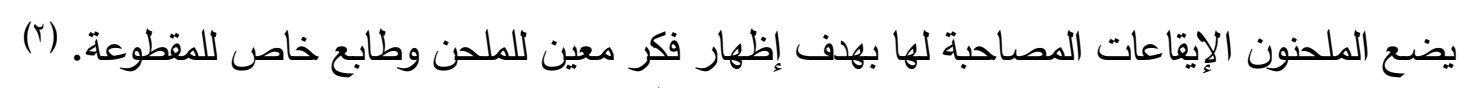

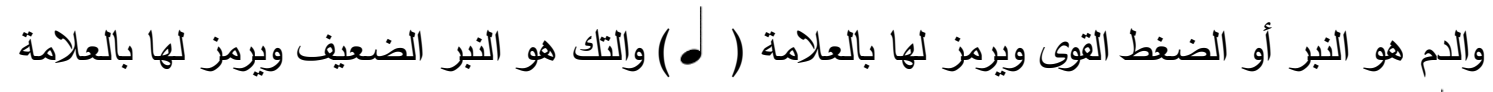

( ) ل الا تضبط الآت الإيقاع على سلم معين بل يكون ضبط الآلة وفقا لإحساس عازف الإيقاع (r).

\section{الجزء الثانى : الإطار التطبيقى : التبطى}

\section{أولا : معايير إعداد التدريبات المقترحة}

تم تقسيم إستخدام السينكوب للشكل الإيقاعى الواحد طبقا للقيمة الزمنية كالاتى

$$
\begin{aligned}
& \text { 1-سينكوب قيمته الزمنية (d) } \\
& \text { r- بينكوب قيمته الزمنية ( •له ) (ل) }
\end{aligned}
$$

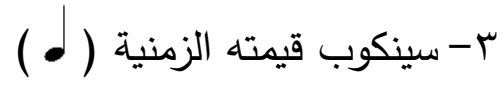

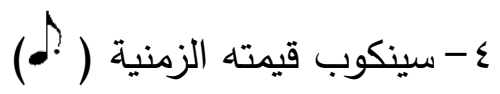

\footnotetext{
(1) Sadie, Stanley: The New Grove Dictionary of Music And Musicians, vol24, Oxford University Press, New York, 2001.p850 
ثانيا : تدريبات مقترحة لبعض أشكال السينكوب الناتجة بإختلاف القيمة الزمنية لهيا

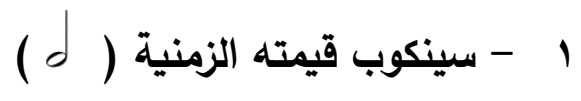

التدريب الأول :

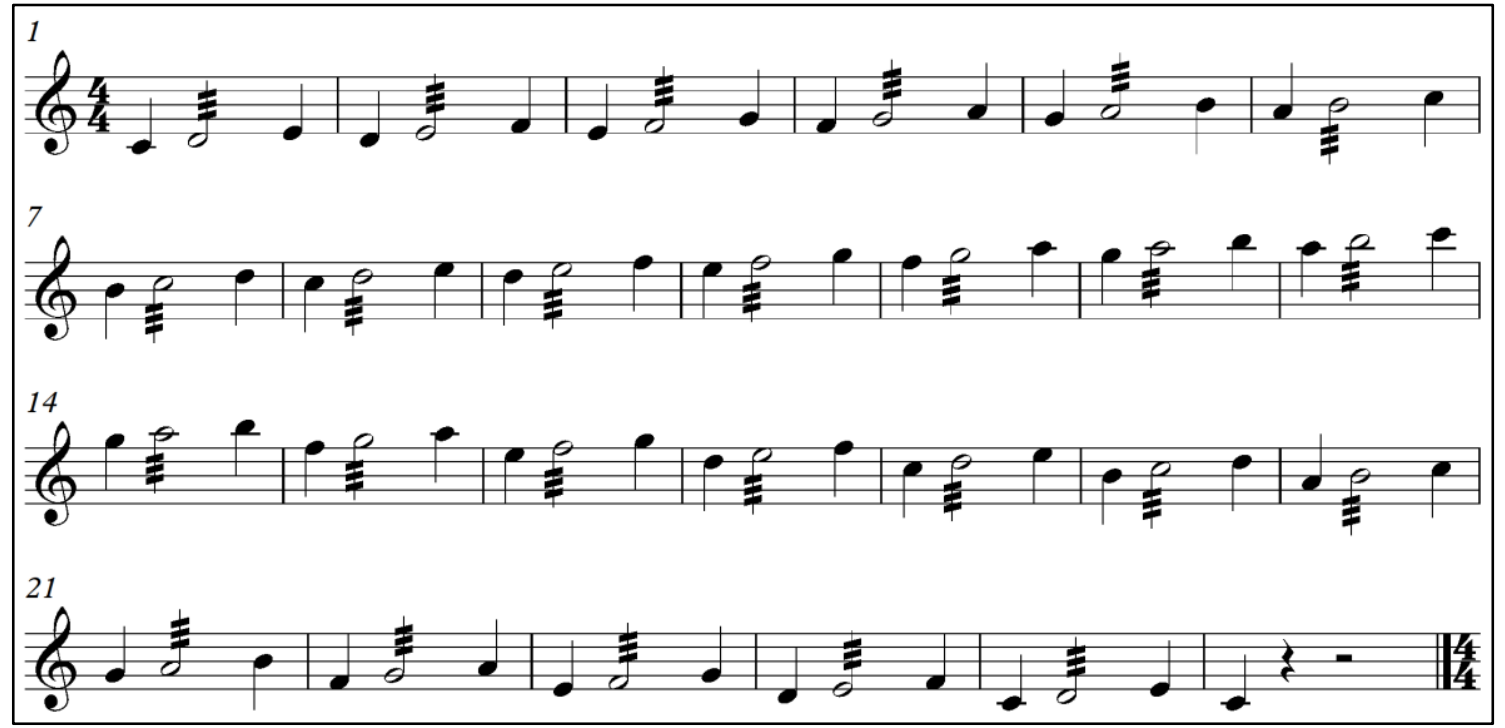

كيفية أداء التدريب : يؤدى هذا التدريب بأسلوب أداء الفرداج مرة فى حدود أوكتاف و مرة بكلتا

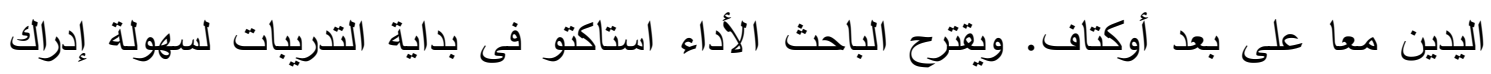
السينكوب دون وجود متغير أخر يحدث التشتت كالفرداج.

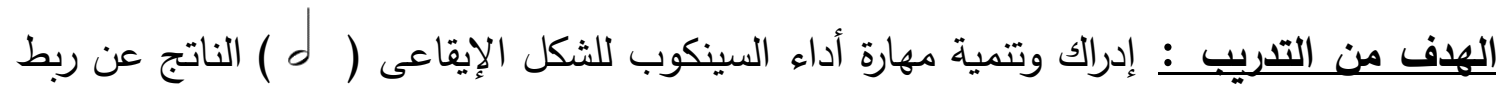

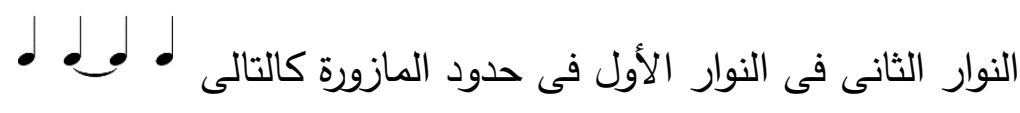


التدربب الثانى :

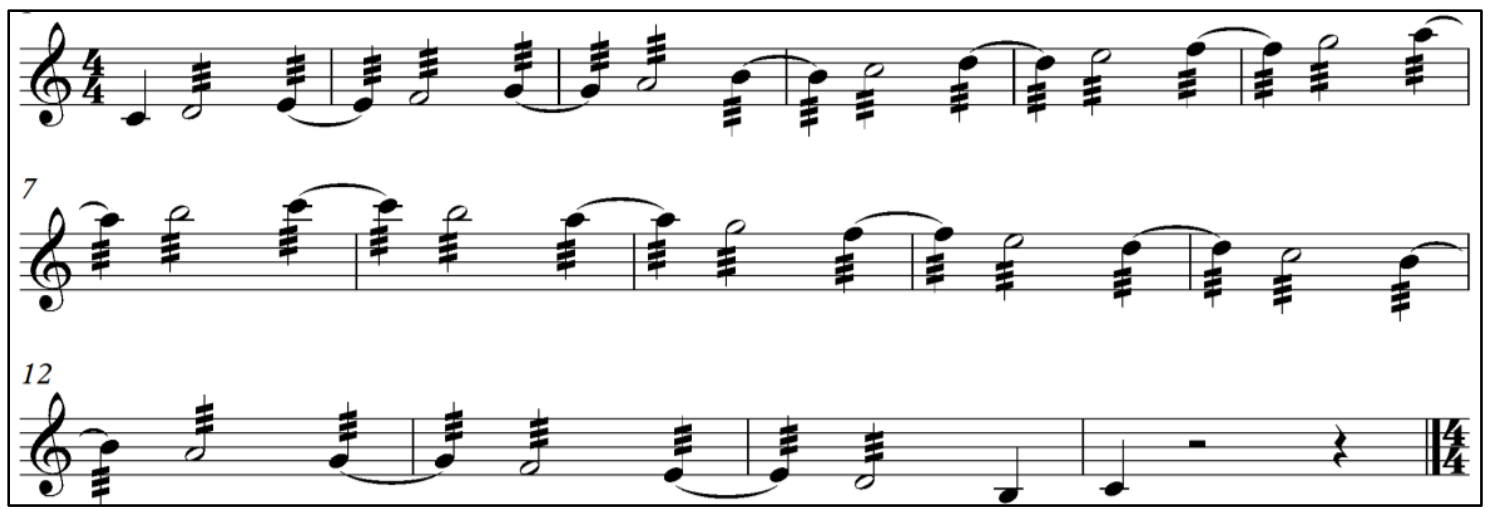

كيفية أداء التدريب : يؤدى هذا التدريب بأسلوب أداء الفرداج مرة فى حدود أوكتاف و مرة بكلتا

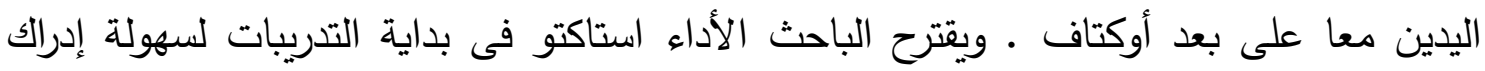
السينكوب دون وجود متغير أخر يحدث التشتت كالفرداج.

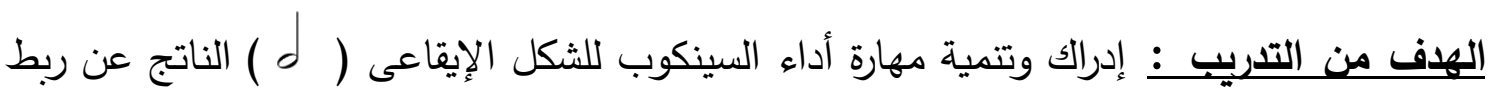

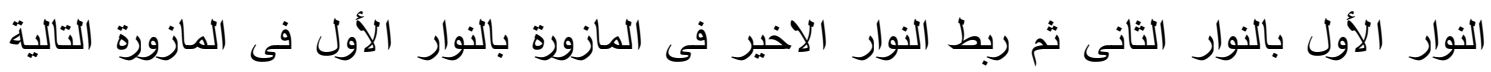

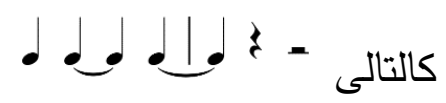

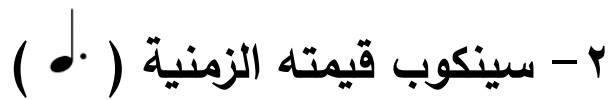

التدريب الثالث :

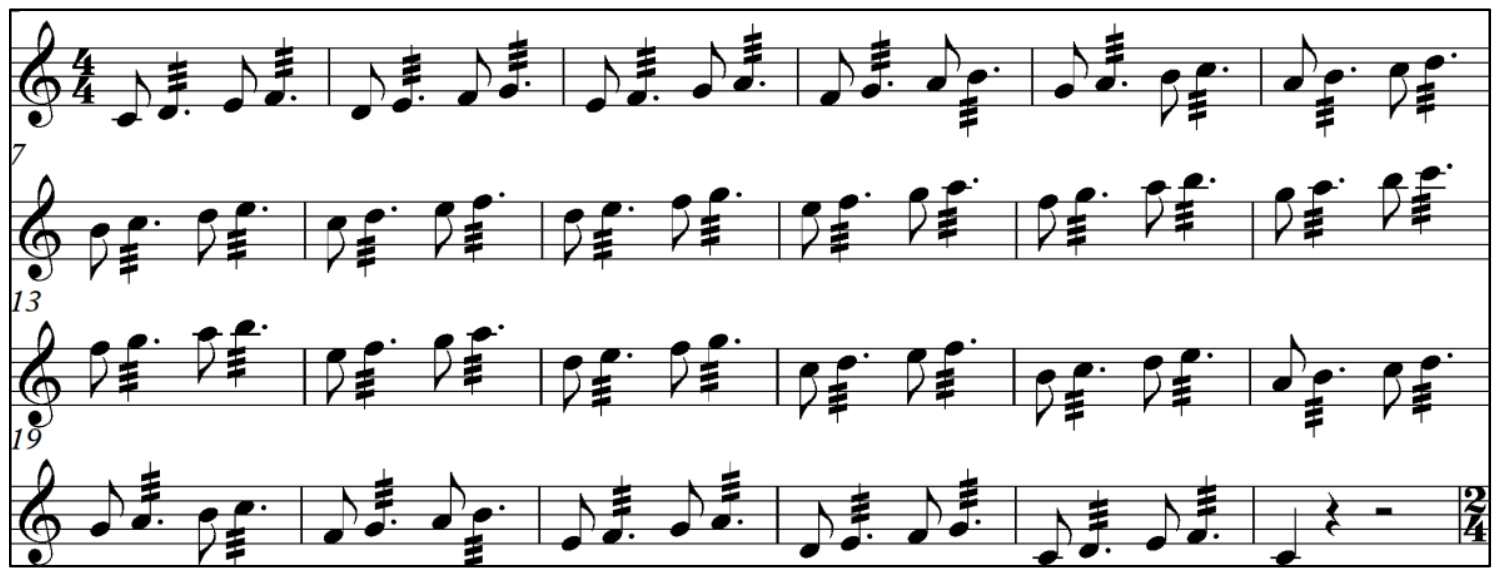

كيفية أداء التتريبـ : يؤدى هذا التدريب بأسلوب أداء الفرداج مرة فى حدود أوكتاف و مرة بكلتا اليدين معا على بعد أوكتاف. ويقترح الباحث الأداء استاكتو فى بداية التدريبات لسهولة إدراك السينكوب دون وجود متغير أخر يحدث التشتت كالفرداج. 
الههف من التدريب : إدراك وتتمية مهارة أداء السينكوب للشكل الإيقاعى ( • م ) الناتج عن ربط النوار الأول بالكروش الأول فى النوار الثانى ثم ربط الكروش الثانى فى النوار الثانى بالنوار الثالث

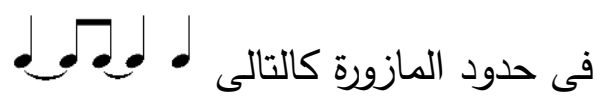
التدريب الرابع :

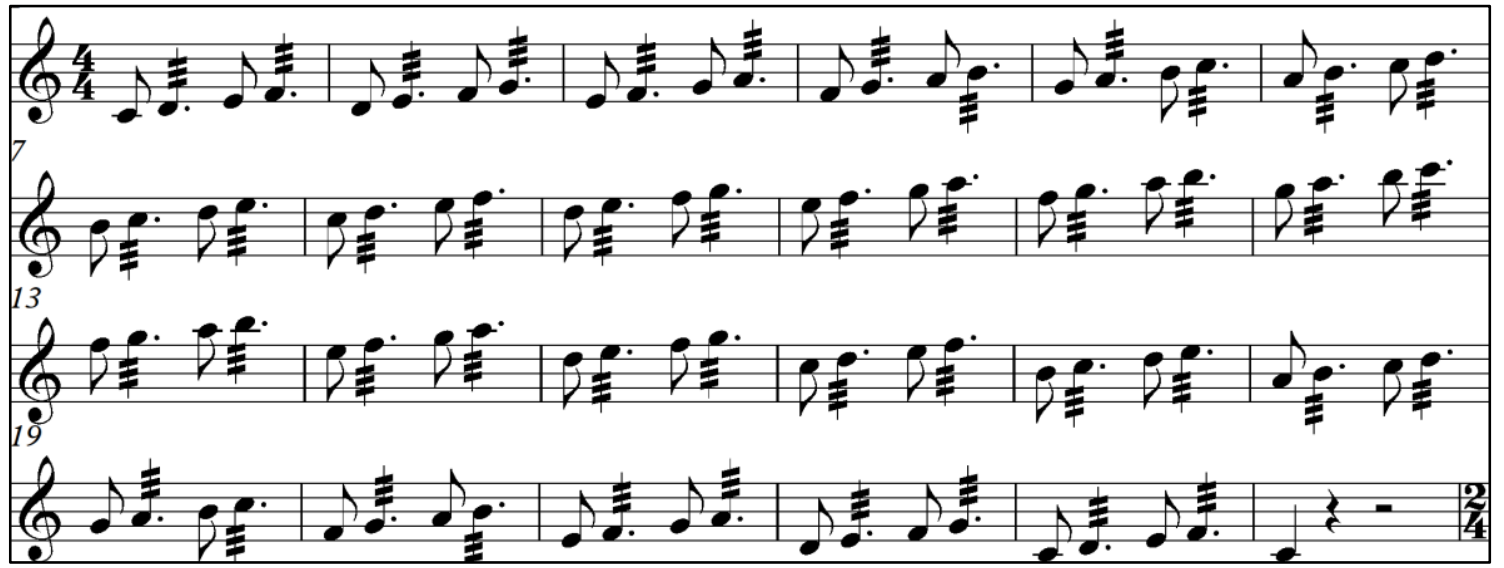

كيفية أداء التدريبـ يؤدى هذا التدريب بأسلوب أداء الفرداج مرة فى حدود أوكتاف و مرة بكلتا اليدين معا على بعد أوكتاف. ويقترح الباحث الأداء استاكتو فى بداية التدريبات لسهولة إدراك السينكوب دون وجود متغير أخر يحدث التشتت كالفرداج.

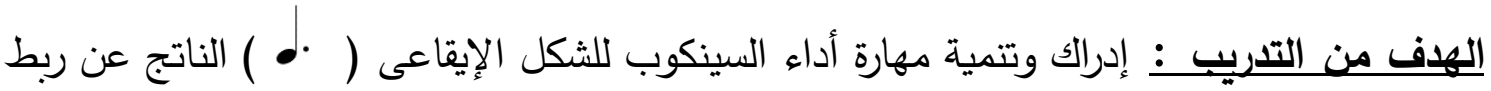

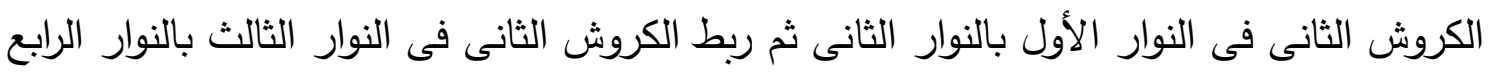

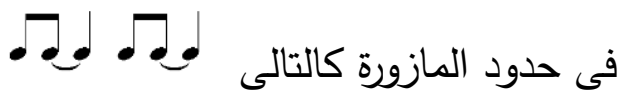




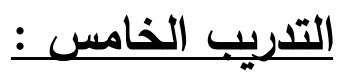

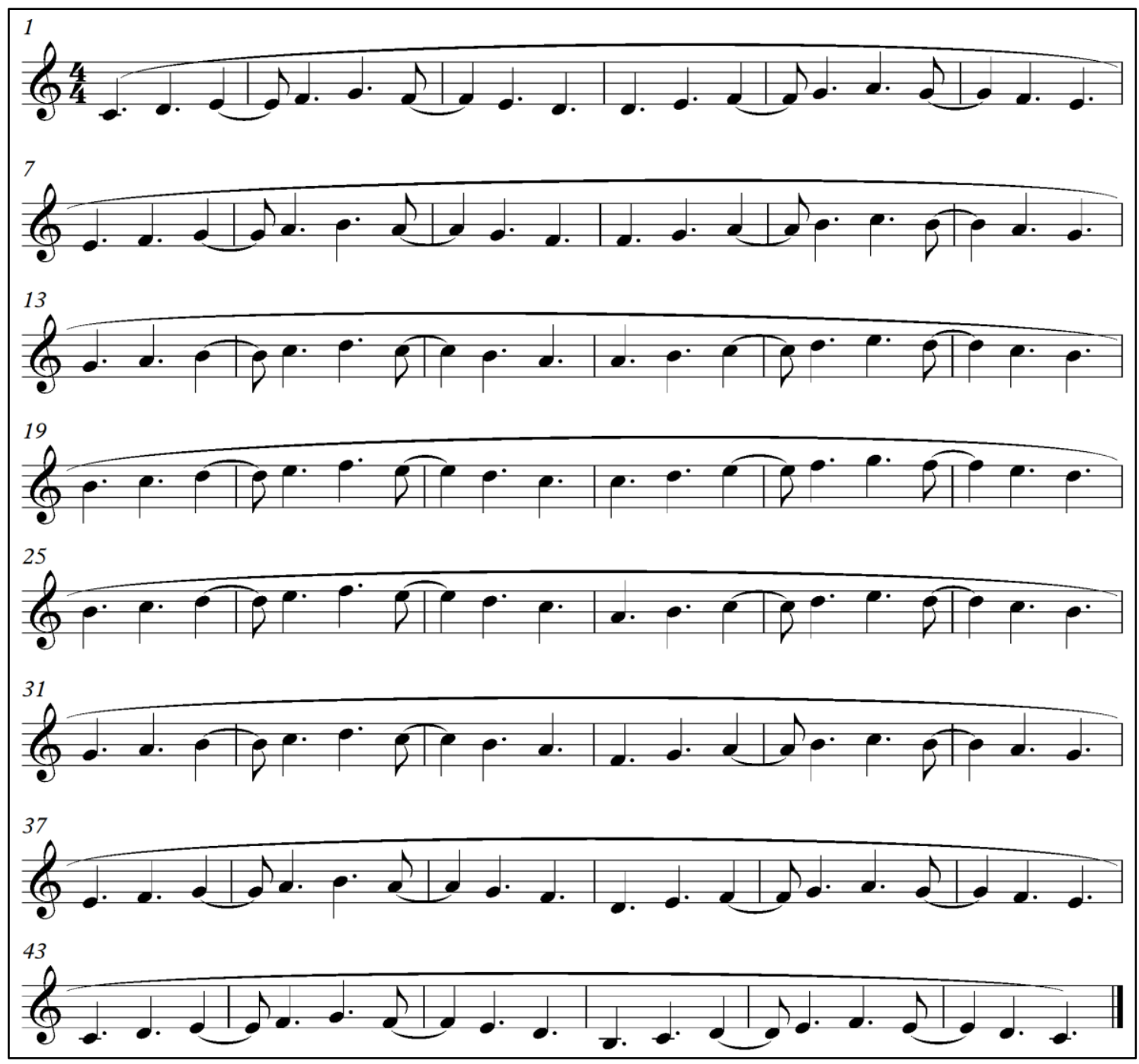

كيفية أداء التدريب : يؤدى هذا التدريب بأسلوب أداء الفرداج مرة فى حدود أوكتاف و مرة بكلتا اليدين معا على بعد أوكتاف. ويتترح الباحث الأداء استاكتو فى بداية التدريبات لسهولة إدراك السينكوب دون وجود متغير أخر يحدث التشتت كالفرداج.

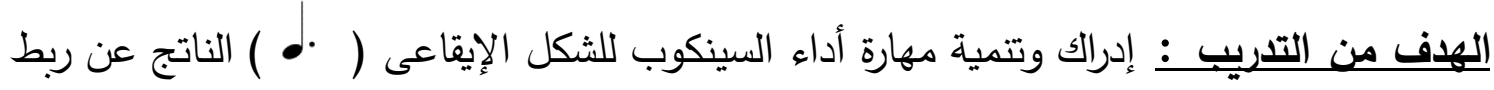

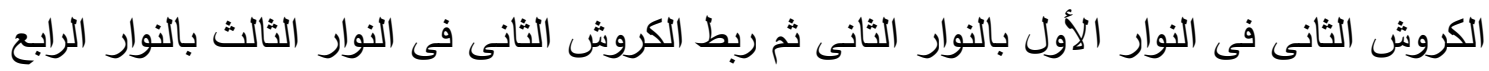

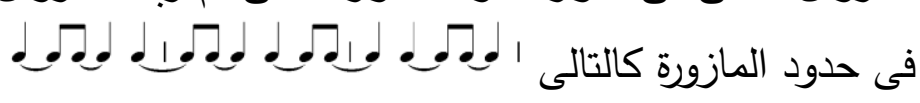

مجلة علوم وفنون الموسيقى - كلية التربية الموسيقية - المجلد الخامس والأربعون - يوليو ا.r.r.

$r \circ \leqslant V$ 


\section{r-سينكوب قيمته الزمنية ( • )}

التدريب السادس :

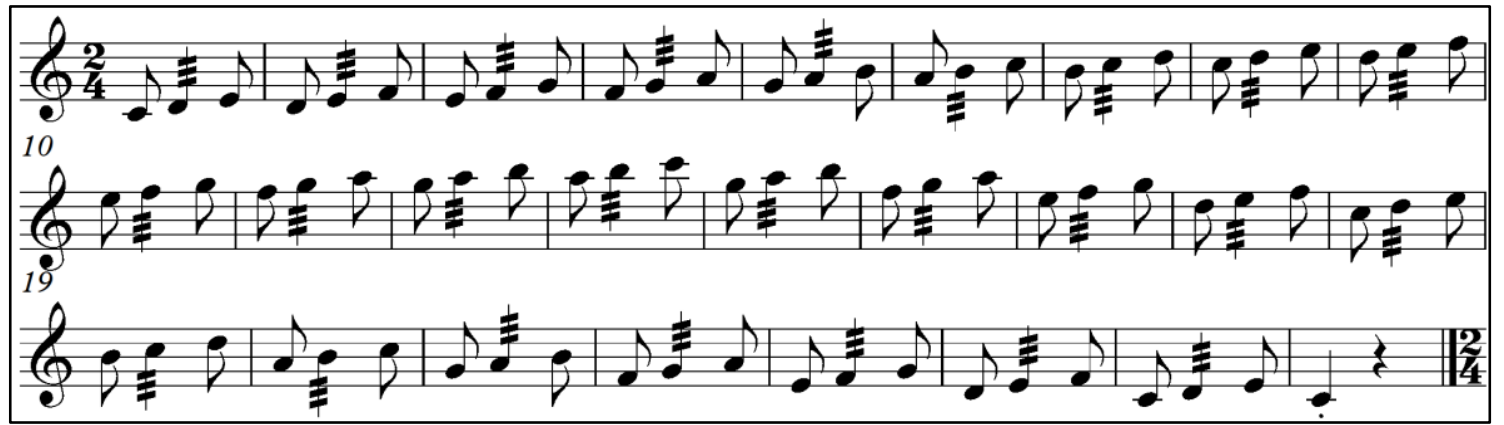

كيفية أداء التدريب : يؤدى هذا التدريب بأسلوب أداء الفرداج مرة فى حدود أوكتاف و مرة بكلتا اليدين معا على بعد أوكتاف. ويقترح الباحث الأداء استاكتو فى بداية التدريبات لسهولة إدراك فئك السينكوب دون وجود متغير أخر يحدث التشتت كالفرداج.

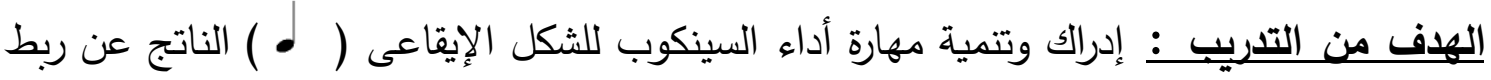
الكروش الثانى فى النوار الأول بالنوار الثانى ثم ربط الكروش الثانى فى النوار الثالث بالنوار الرابع الثاء

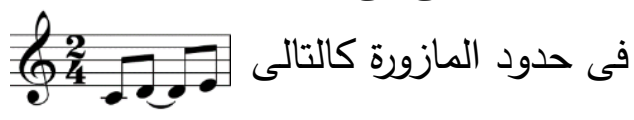
التدريب السابع :

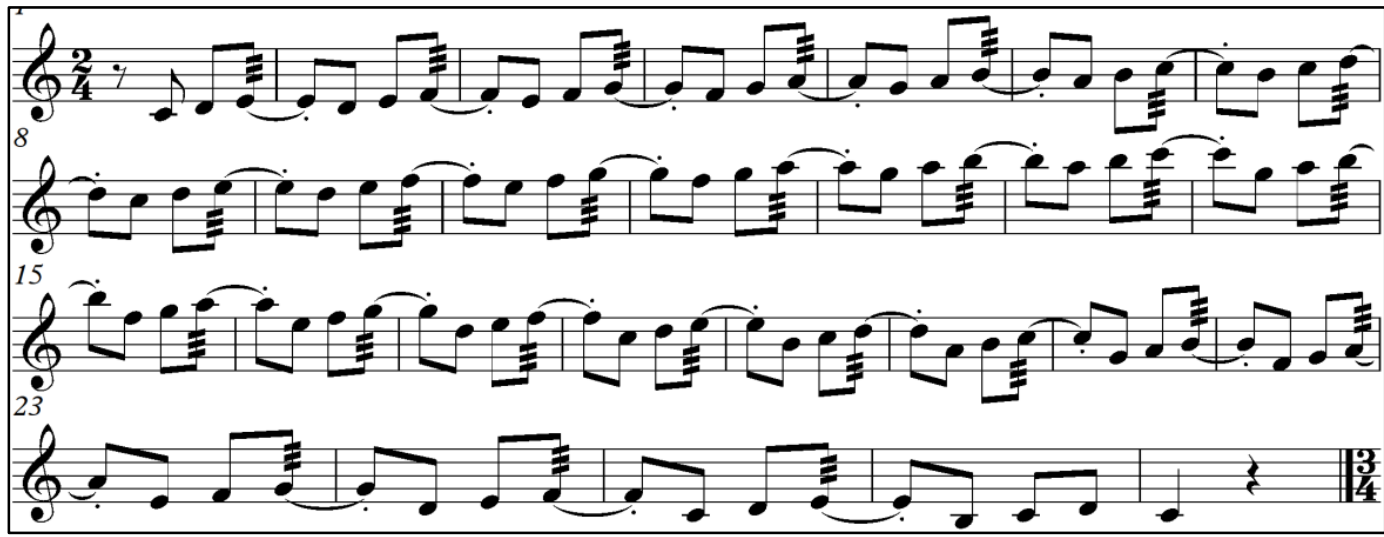

كيفية أداء التدريب: يؤدى هذا التدريب بأسلوب أداء الفرداج مرة فى حدود أوكتاف و مرة بكلتا اليدين معا على بعد أوكتاف. ويتترح الباحث الأداء استاكتو فى بداية التدريبات لسهولة إدراك السينكوب دون وجود متغير أخر يحدث التثتت كالفرداج. 
اللهذف من التدريب : إدراك وتتمية مهارة أداء السينكوب للثكل الإيقاعى ( • ) الناتج عن ربط الكروش الثانى فى النوار الثانى بالكروش الأول فى النوار الأول فى المازورة الجديدة كالتالى

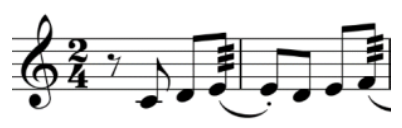

التدريب الثامن :

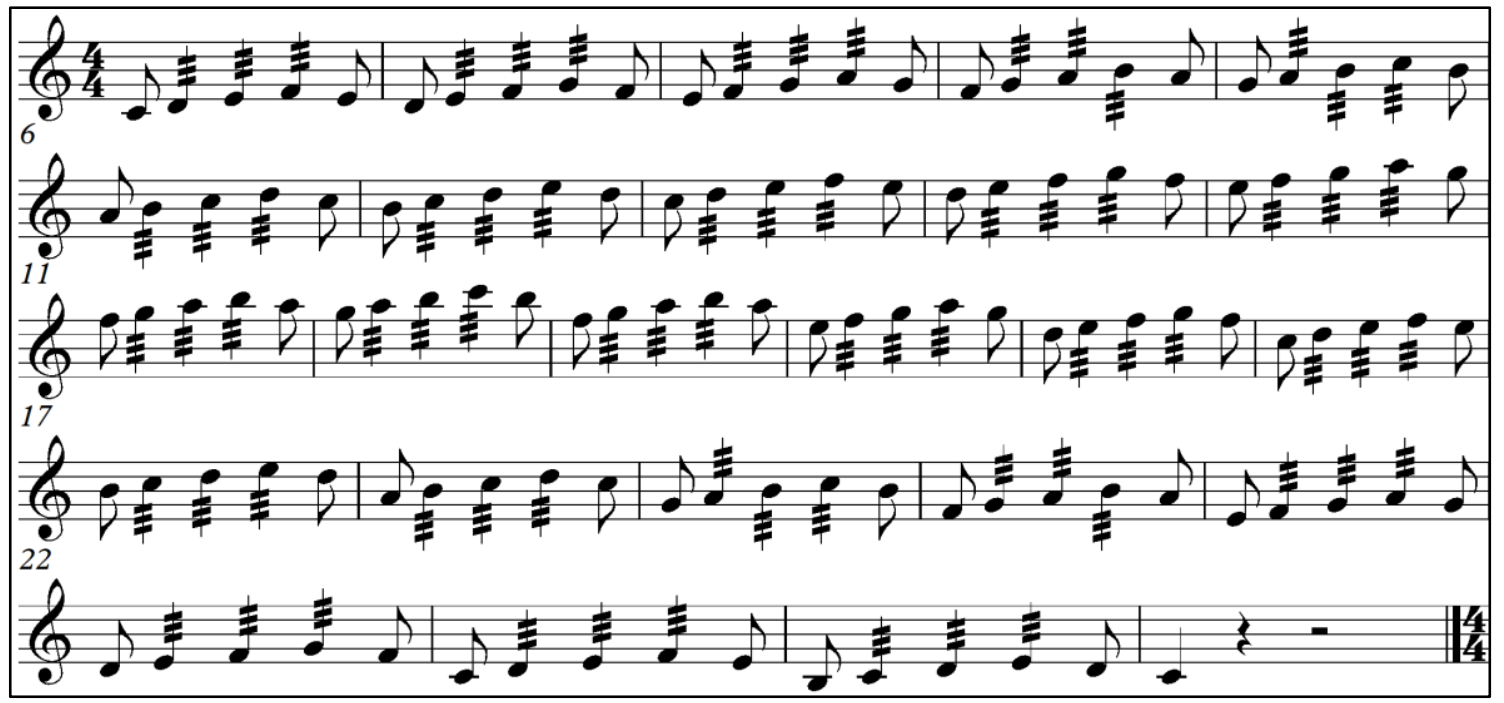

كيفية أداء التدريب : يؤدى هذا التدريب بأسلوب أداء الفرداج مرة فى حدود أوكتاف و مرة بكلتا اليدين معا على بعد أوكتاف. ويقترح الباحث الأداء استاكتو فى بداية التدريبات لسهولة إدراك السينكوب دون وجود متغير أخر يحدث التشتت كالفرداج.

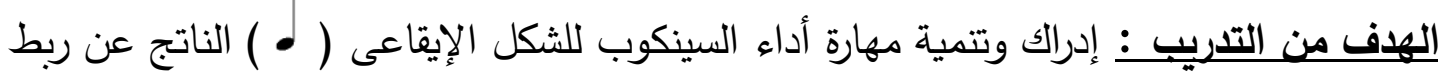
الكروش الثانى فى النوار الأول بالكروش الأول فى النوار الثانى ثم ربط الكروش الثانى فى النوار

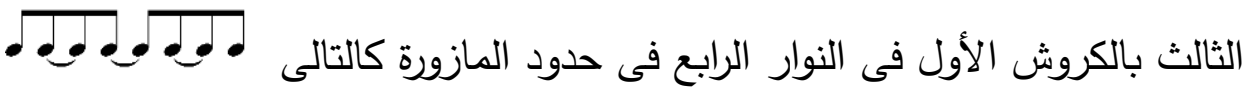
التدربب التاسع : بـ

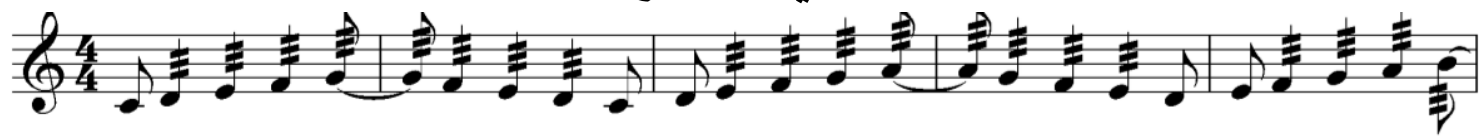

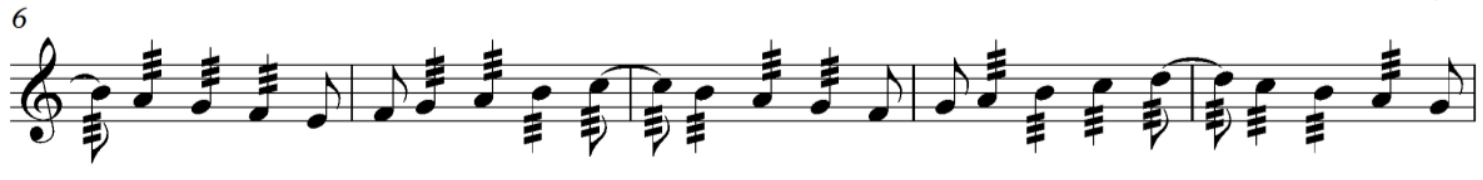




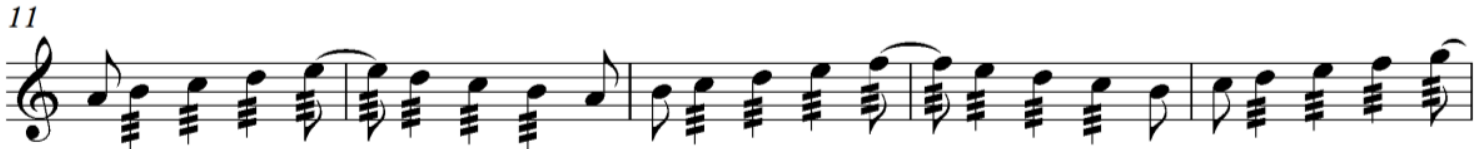

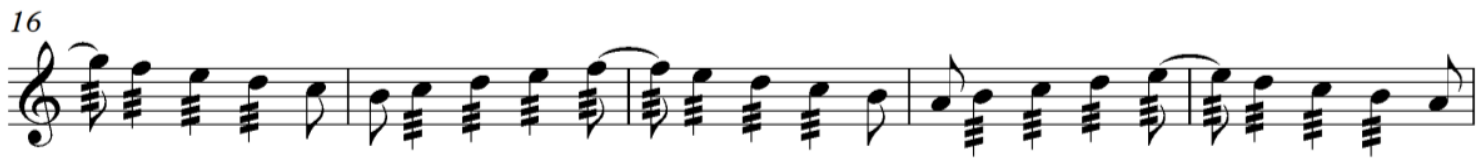
21
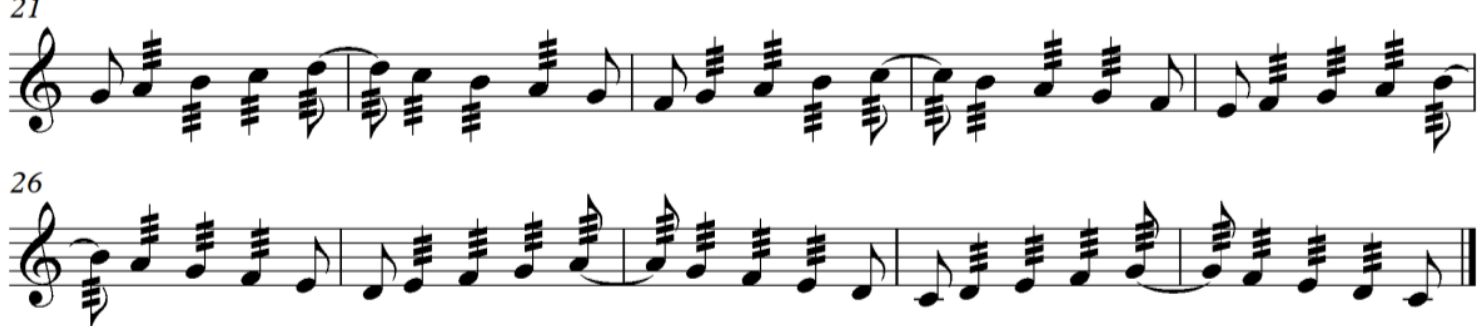

كيفية أداء التدريب : يؤدى هذا التدريب بأسلوب أداء الفرداج مرة فى حدود أوكتاف و مرة بكلتا اليدين معا على بعد أوكتاف. ويقترح الباحث الأداء استاكتو فى بداية التدريبات لسهولة إدراك السينكوب دون وجود متغير أخر يحدث التشتت كالفرداج. الههف من التدربب : إدراك وتتمية مهارة أداء السينكوب للشكل الإيقاعى ( • ) الناتج عن ربط الكروش الثانى فى النوار الأول بالكروش الأول فى النوار الثانى ثم ربط الكروش الثانى فى النوار الثالث بالكروش الأول فى النوار الرابع فى المازورة ثم ربط الكروش الثانى فى النوار الرابع

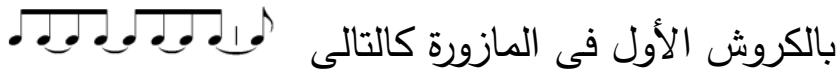
التدربِب العاشر :

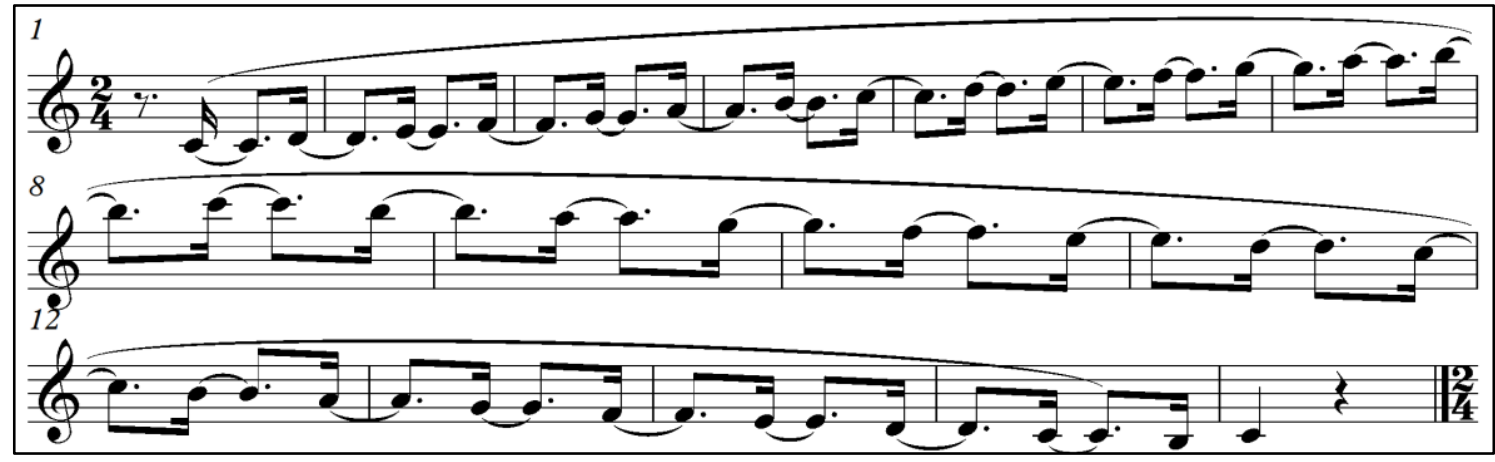

كيفية أداء التدريب : يؤدى هذا التدريب بأسلوب أداء الفرداج مرة فى حدود أوكتاف و مرة بكلتا اليدين معا على بعد أوكتاف. ويقترح الباحث الأداء استاكتو فى بداية التدريبات لسهولة إدراك السينكوب دون وجود متغير أخر يحدث التشتت كالفرداج.

مجلة علوهر وفنوز الموسيقى - كلية التربية الموسيقية - المجلد الخامس والأربعوز - يوليو ابمبمر 
الإهف من التدريب : إدراك وتتمية مهارة أداء السينكوب للثكل الإيقاعى ( • ) الناتج عن ربط

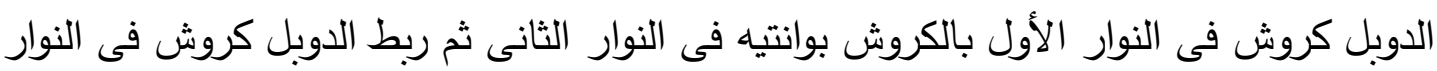

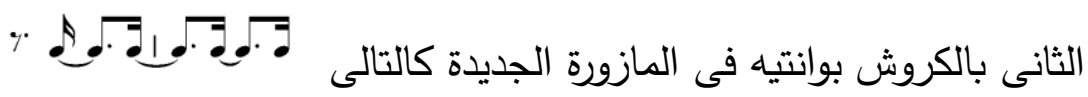
التدريب الحادى عشر :

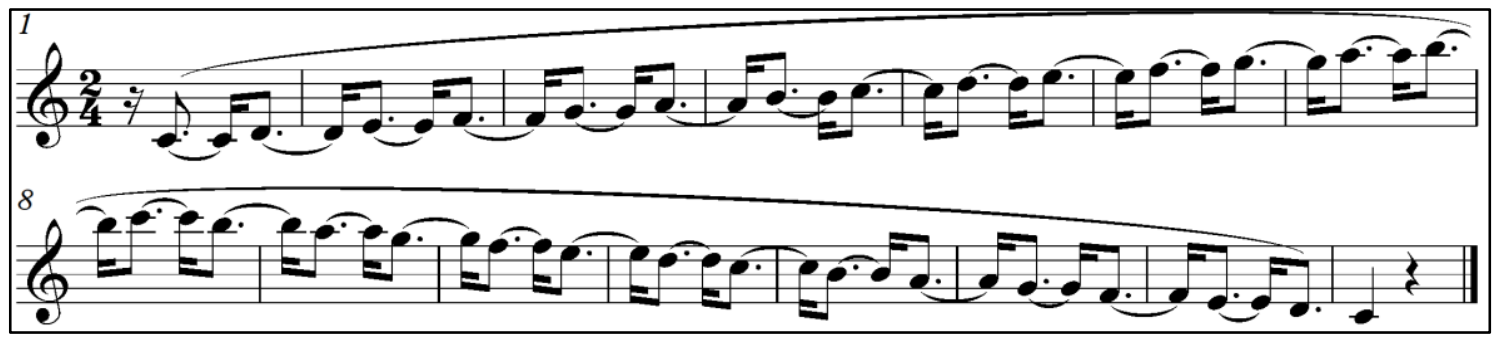

كيفية أداء التدريب : يؤدى هذا التدريب بأسلوب أداء الفرداج مرة فى حدود أوكتاف و مرة بكلتا اليدين معا على بعد أوكتاف. ويقترح الباحث الأداء استاكتو فى بداية التدريبات لسهولة إدراك السينكوب دون وجود متغير أخر يحدث التشتت كالفرداج. الإهف من التدريب : إدراك وتتمية مهارة أداء السينكوب للثكل الإيقاعى ( • ) الناتج عن ربط ليط كروش بوانتيه فى النوار الأول بالدوبل كروش فى النوار الثانى ثم ربط كروش بوانتيه فى النوار

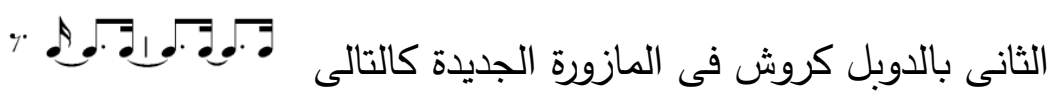

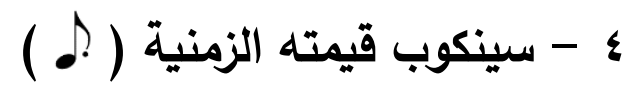
التدريب الثانى عشر

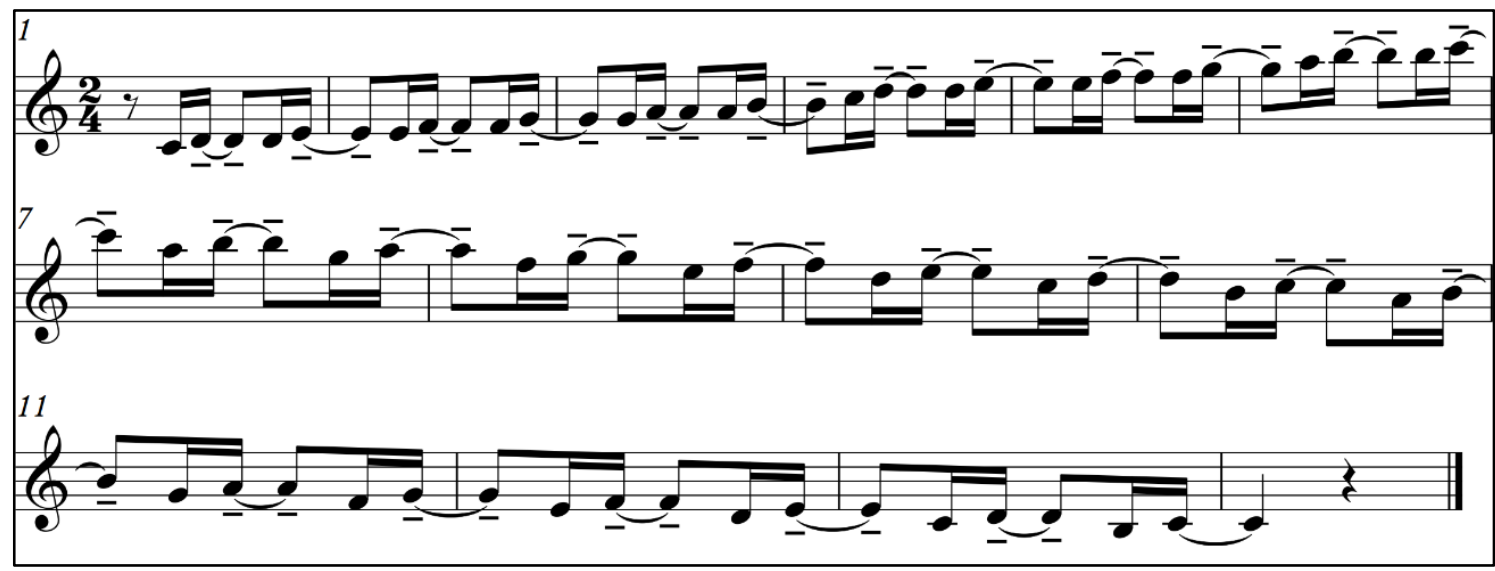

كيفية أداء التدريب : يؤدى هذا التدريب بأسلوب أداء ال ( détaché ) وهو أداء الفرداش غير

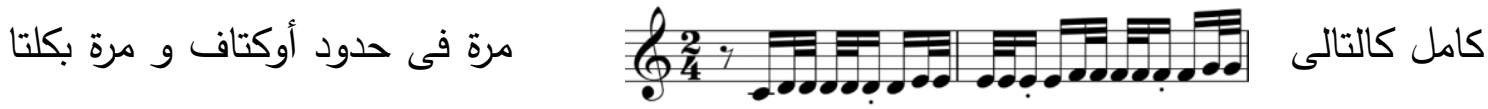


اليدين معا على بعد أوكتاف. ويقترح الباحث الأداء استاكتو فى بداية التدريبات لسهولة إدراك السينكوب دون وجود متغير أخر يحدث التشتت كالفرداج.

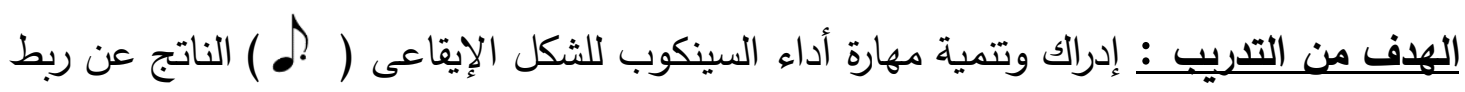

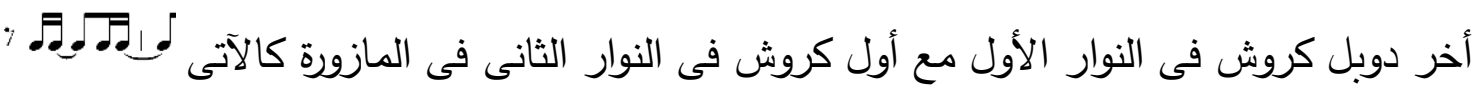
التدريب الثالث عشر :

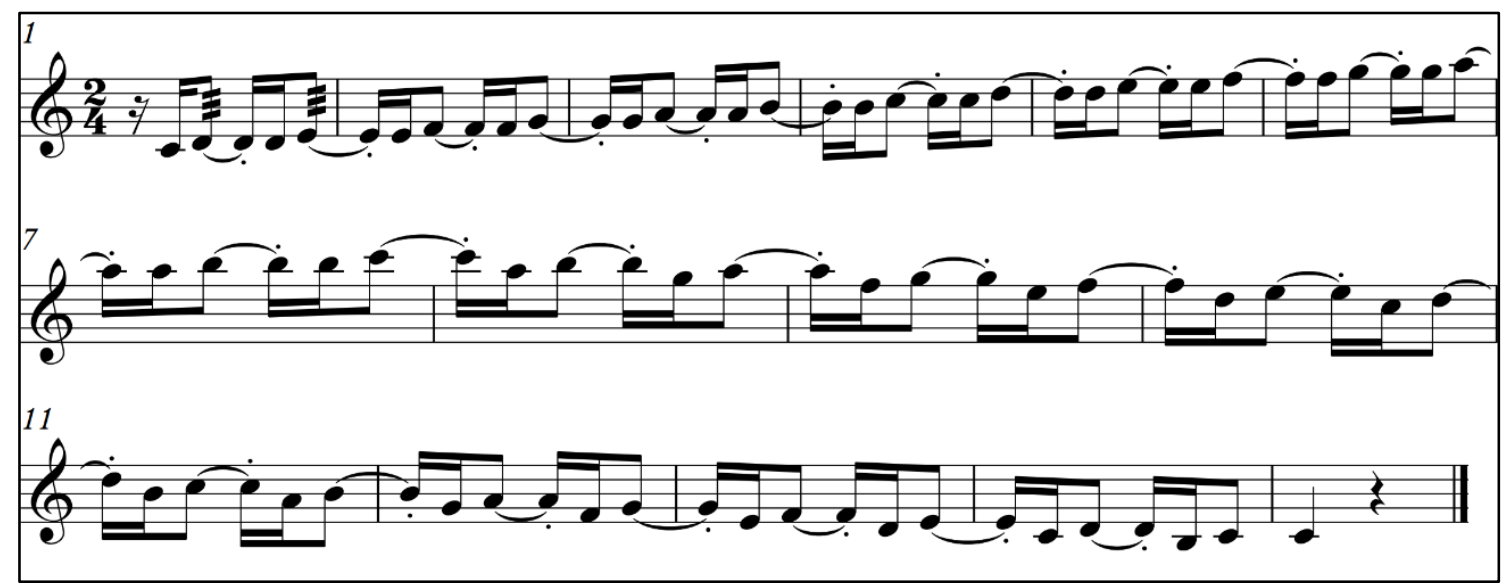

كيفية أداء التدريب : يؤدى هذا التدريب بأسلوب أداء الفرداج مرة فى حدود أوكتاف و مرة بكلتا اليدين معا على بعد أوكتاف. ويقترح الباحث الأداء استاكتو فى بداية التدريبات لسهولة إدراك السينكوب دون وجود متغير أخر يحدث التشتت كالفرداج.

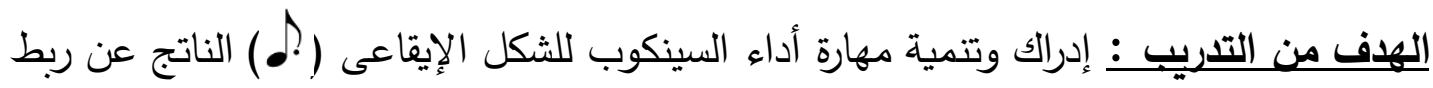
الكروش فى النوار الأول بالدوبل كروش الأول فى النوار الثانى ثم ربط الكروش فى النوار الثانى

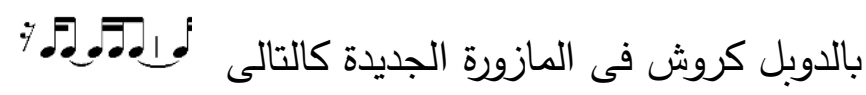

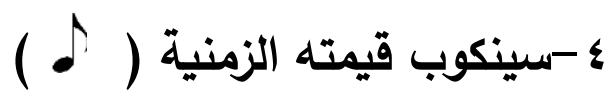
التدربب الرابع عشر :

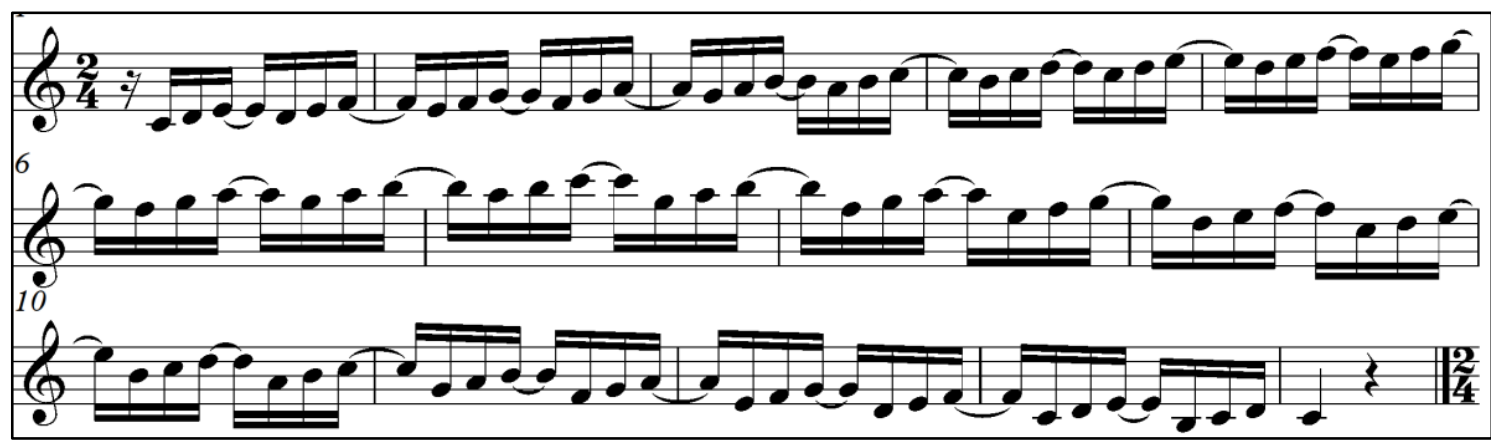

مجلة علوم وفنون الموسيقى - كلية التربية الموسيقية - المجلد الخامس والأربعون - يوليو اب.rم 
كيفية أداء التدريب : يؤدى هذا التدريب بأسلوب أداء الفرداج مرة فى حدود أوكتاف و مرة بكلتا اليدين معا على بعد أوكتاف. ويقترح الباحث الأداء استاكتو فى بداية التدرببات لسهولة إدراك السينكوب دون وجود متغير أخر يحدث التشتت كالفرداج.

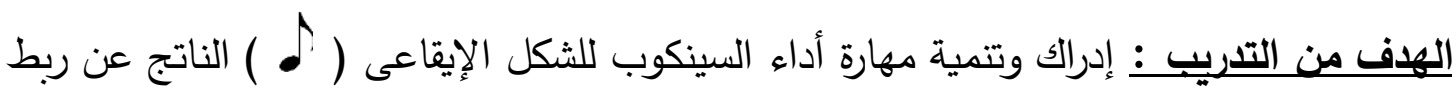

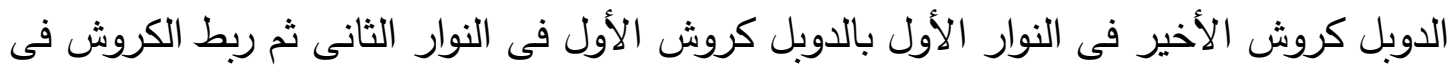

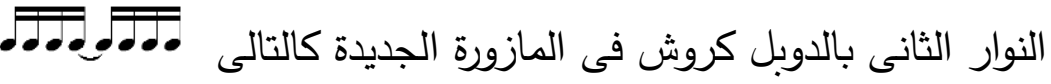
التدريب الخامس عشر :

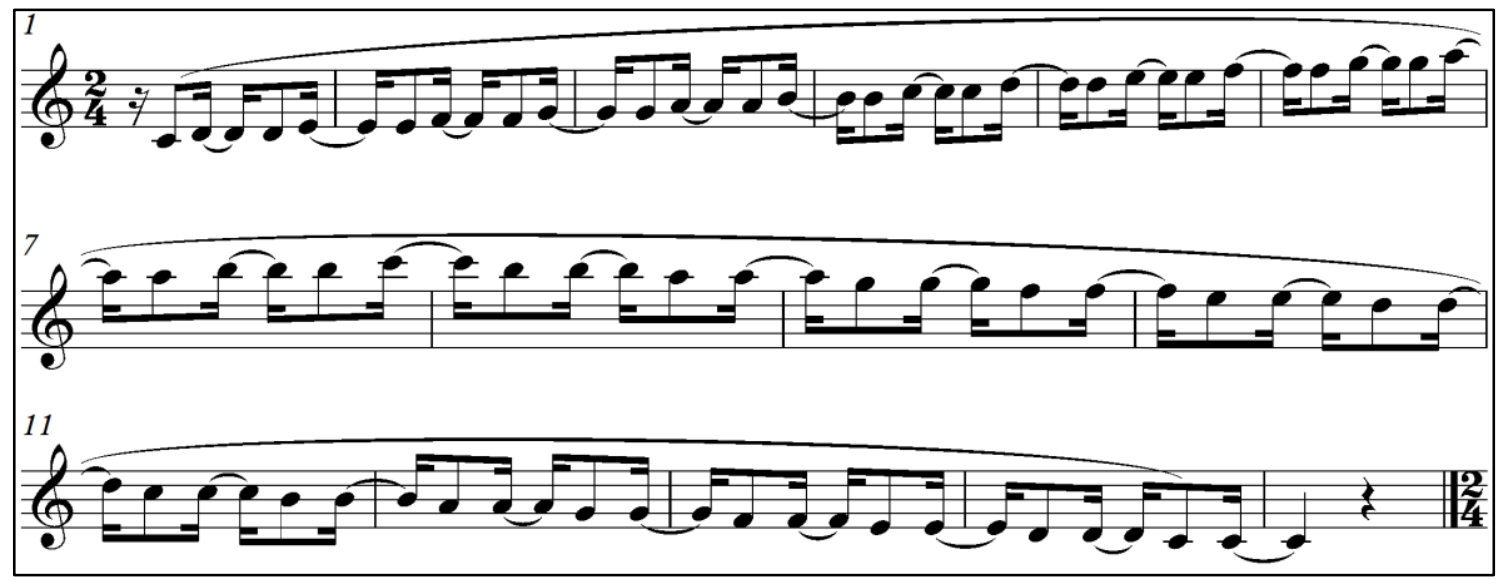

كيفية أداء التدريب : يؤدى هذا التدريب بأسلوب أداء الفرداج مرة فى حدود أوكتاف و مرة بكلتا اليدين معا على بعد أوكتاف. ويقترح الباحث الأداء استاكتو فى بداية التدريبات لسهولة إدراك السينكوب دون وجود متغير أخر يحدث التشتت كالفرداج.

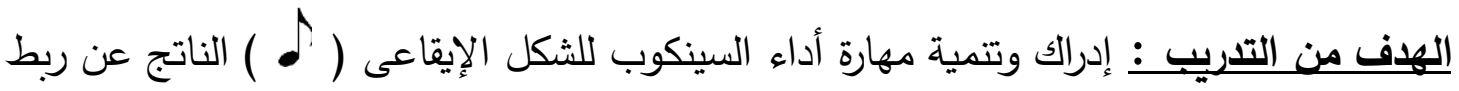

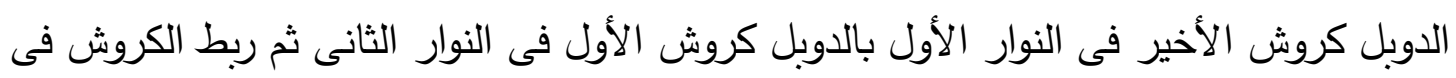
.0.9. النوار الثانى بالدوبل كروش فى المازورة الجديدة كالتالى نتائج البحث : بعد إتمام الاراسة قام الباحث بعرض التدريبات المقترحة وعددها خمس عشر تدريبا على بعض الأساتذة الخبراء وعددهم ثمانية أساتذة فى صورة استفتاء من النوع المقيد ويعرض الباحث فيما يلى نتائج الإستفتاء

مجلة علوم وفنون الموسيقى - كلية التربية الموسيقية - المجلد الخامس والأربعون - يوليو اب.rم 
- جاءت نتيجة الإستفتاء إيجابية بنسبة ( ץ.؟ \% \% ) تبعا للنسب الإحصائية

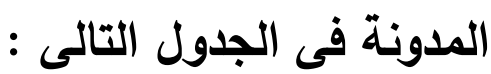

\begin{tabular}{|c|c|c|c|}
\hline النسبة المئوية & الموافقون & عدد الخبراء & التدريبات المقترحة \\
\hline$\% 1$. & v & $v$ & التتريب الأول \\
\hline$\%$ & $\mathrm{v}$ & $v$ & التاريب الثانى \\
\hline$\% 1 .$. & $v$ & $v$ & الترريب الثالث \\
\hline$\% \vee 1 . \varepsilon$ & - & $v$ & التاريب الزرايع \\
\hline$\%$ & $\mathrm{v}$ & $\mathrm{v}$ & التلريب الخامس \\
\hline$\% 1 .$. & $v$ & $v$ & التدريب السادس \\
\hline$\%$ \%०.v & 9 & $v$ & التلريب السابع \\
\hline$\%$ & $\mathrm{v}$ & $v$ & التدريب الثامن \\
\hline$\%$ & v & $\mathrm{v}$ & التدريب التاسع \\
\hline$\% \vee 1 . \varepsilon$ & - & $v$ & التدريب العاشر \\
\hline$\% 1$. & v & $\mathrm{v}$ & التريب الحادى عثر \\
\hline$\%$ & $v$ & $\mathrm{v}$ & التلريب الثانى عشر \\
\hline$\%$ & $\mathrm{v}$ & $\mathrm{v}$ & التريب الثالث عشر \\
\hline$\%$ \%०.V & 4 & $\mathrm{v}$ & التدريب الرابع عثر \\
\hline$\%$ & $\mathrm{v}$ & $v$ & التدريب الخامس عشر \\
\hline
\end{tabular}

1- الاهتمام بتدريبات السينكوب لأهميته ف مدونات الموسيقة العربية . r- الاعتماد على قراءة وكتابة المدونات الموسيقية بكافة تفاصيلها وعدم الإعتماد على التلقين فى التدريس ץ-الإهتمام بأن يكون المؤلف الموسيقى العبى على دراية تامة بإمكانيات آلة القانون حتى يتسنى له الكتابة المناسبة لآلة القانون 


\section{مراجع البحث:}

أولا : المراجع باللغة العربية:

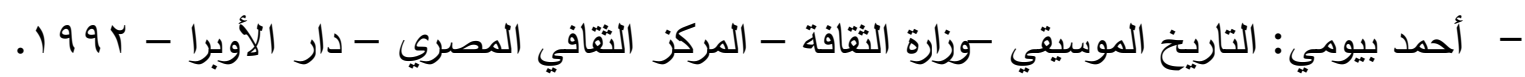

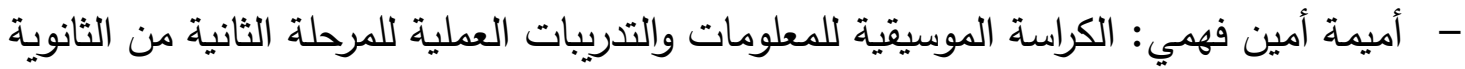

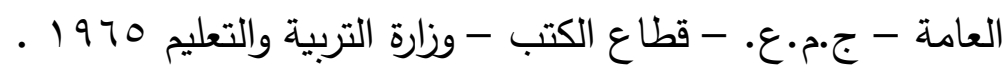
- - أميمة أمين, عائشة سليم: الموضوعات الدالكروزية بين النظرية والتطبيق فى الإيقاع الحركى,

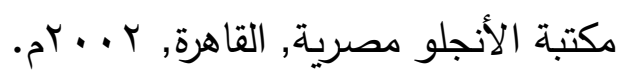

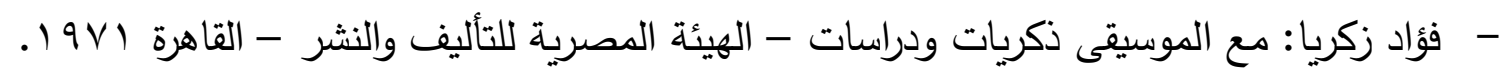

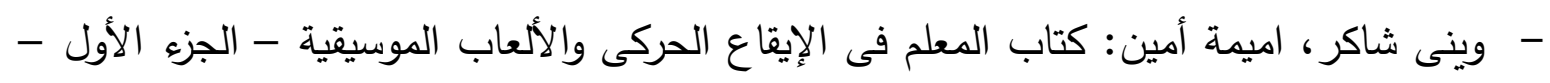

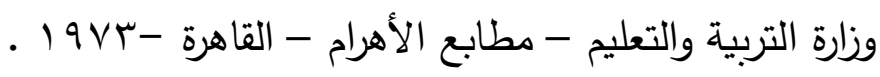

\section{ثانيا : المراجع باللغة الإنجليزية :}

- Apel, Willi: Harvard Dictionary of Music, London Heimmann Educational Book's LTD, 1971.

- Barry Kernfeld: The New Groves Dictionary of Jazz - Vol. 1 - USA 1988.

- Cooper Grosvwpenor, Mayer, Leonard: The Rhythmic Structure of Music - Chicago University - USA 1963.

- Sadie, Stanley: The New Grove Dictionary of Music And Musicians, vol24, Oxford University Press, New York, 2001.

\section{ثالثا : رسائل دكتوراة :}

- - ـإيمان حسين عبد الحميد جنيد : برنامج مقترح لتذليل صعوبات أداء المؤلفات المعاصرة ذات

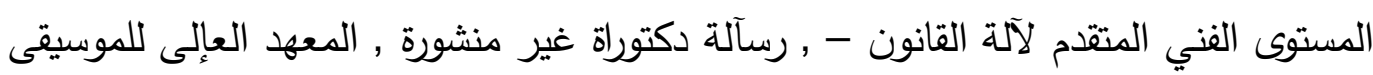

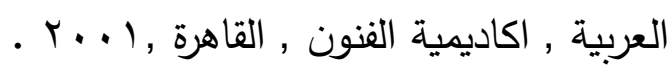
- صابر عبد الستار: دور آلة القانون فى الأوركسترا من خلال بعض المأل المؤلفات الحديثة, رسآلة

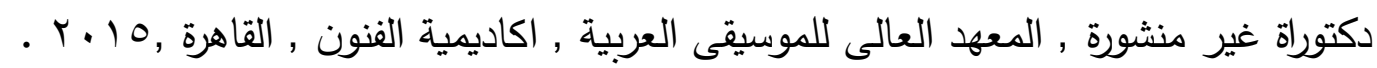




\section{لإيعا : الأبحاث المنشورة :}

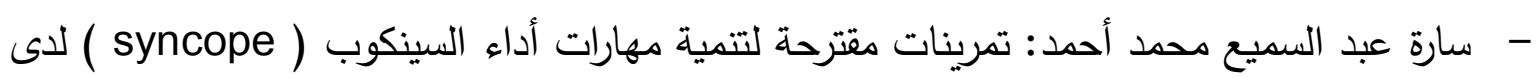
الطالب المعلم مستنبطة من موسيقى لعبة ( سوبر ماريو ),بحث منشور , المجلد السابع والثثلاثثن,

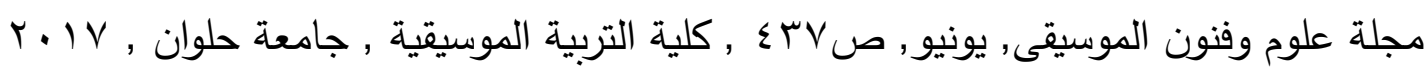

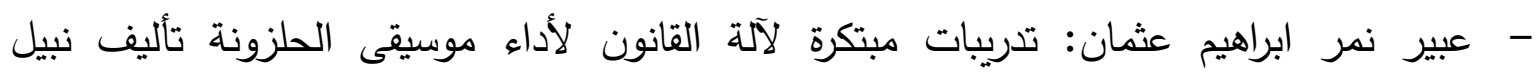

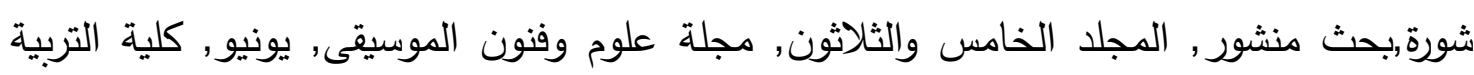

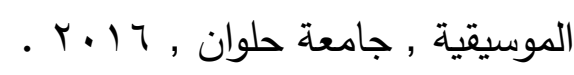
- مرام جلال توفيق زكى: فاعلية ورشة عمل لتذليل بعض الصعوبات الإيقاعية فى مدونات المقررات العزفية,بحث منشور , المجلد السابع والثثلاثون, مجلة علوم وفنون الموسيقى, جعاء , كلية

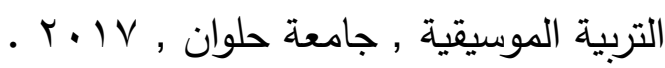




\section{ملحق البحث (1)}

استمارة استطلاع أىى الخبراء

تحية طيبة وبعد,

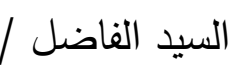

"Syncope" يقوم الباحث بإجراء دراسة بعنوان " تدريبات مقترحة لتتمية مهارات أداء السينكوب طئة

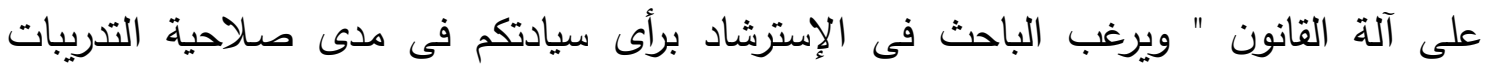
المقترحة ومدى ملائمتها للهدف منها. نرجو من سيادتكم التكرم بوضع علامة فى الخانة التى تتاسب رأى سيادتكم مع ذكر الملاحظات ان وجدت ولكم جزيل الثكر ل معايير إعداد التريبيات المقترحة تم تقسيم إستخدام السينكوب للثكل الإيقاعى الواحد طبقا للقيمة الزمنية لإعداد التدريبات كالاتى

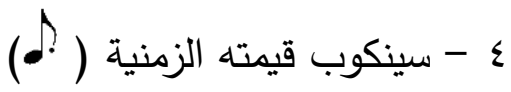

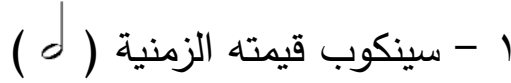

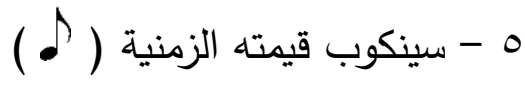

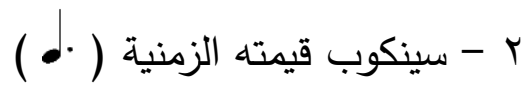

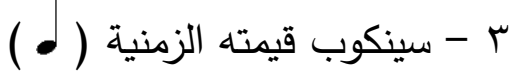

التدربب الأول

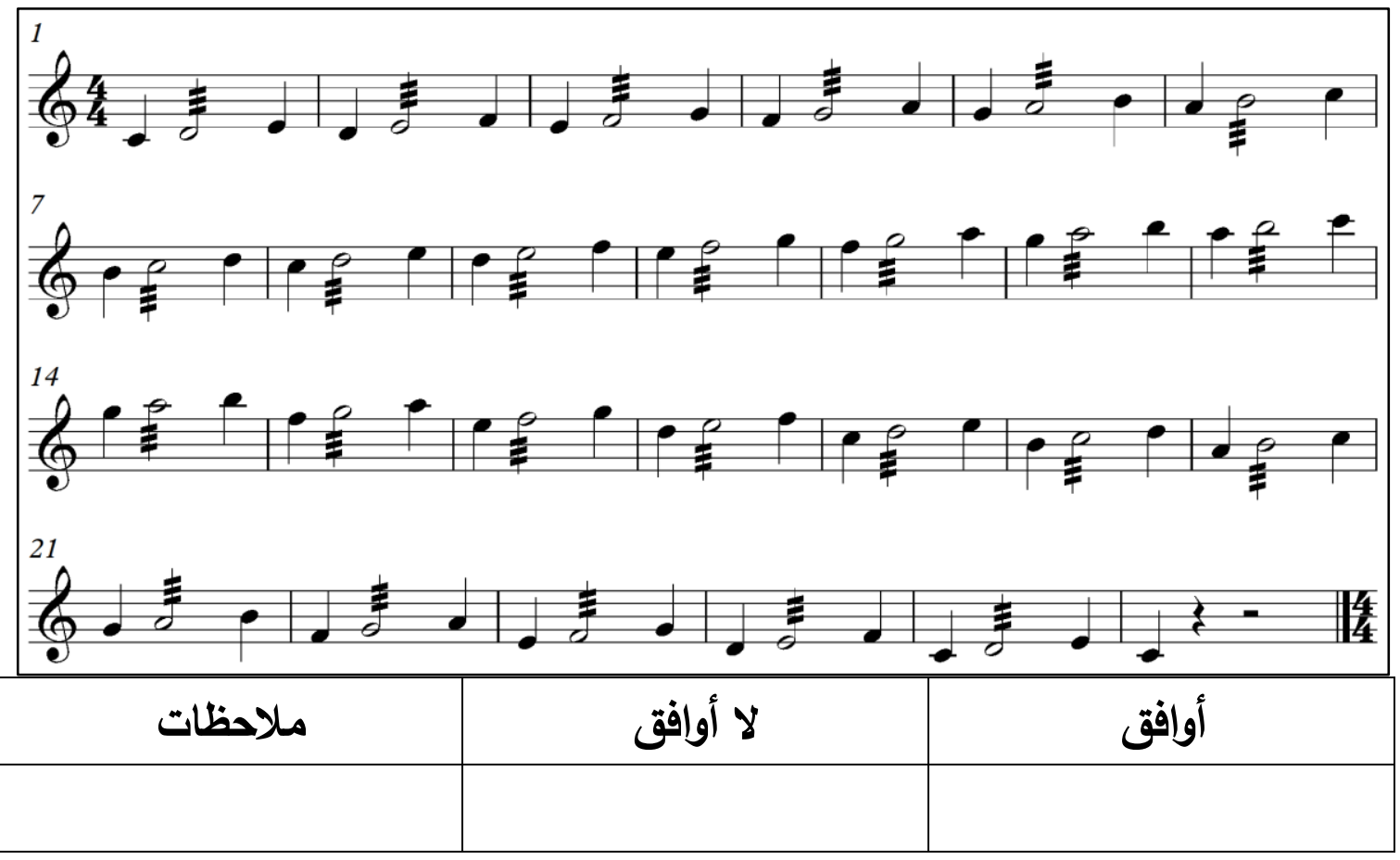

مجلة علوم وفنون الموسيقى - كلية التربية الموسيقية - المجلد الخامس والأربعوذ - يوليو اب.rم 


$$
\text { التدريب الثانى }
$$

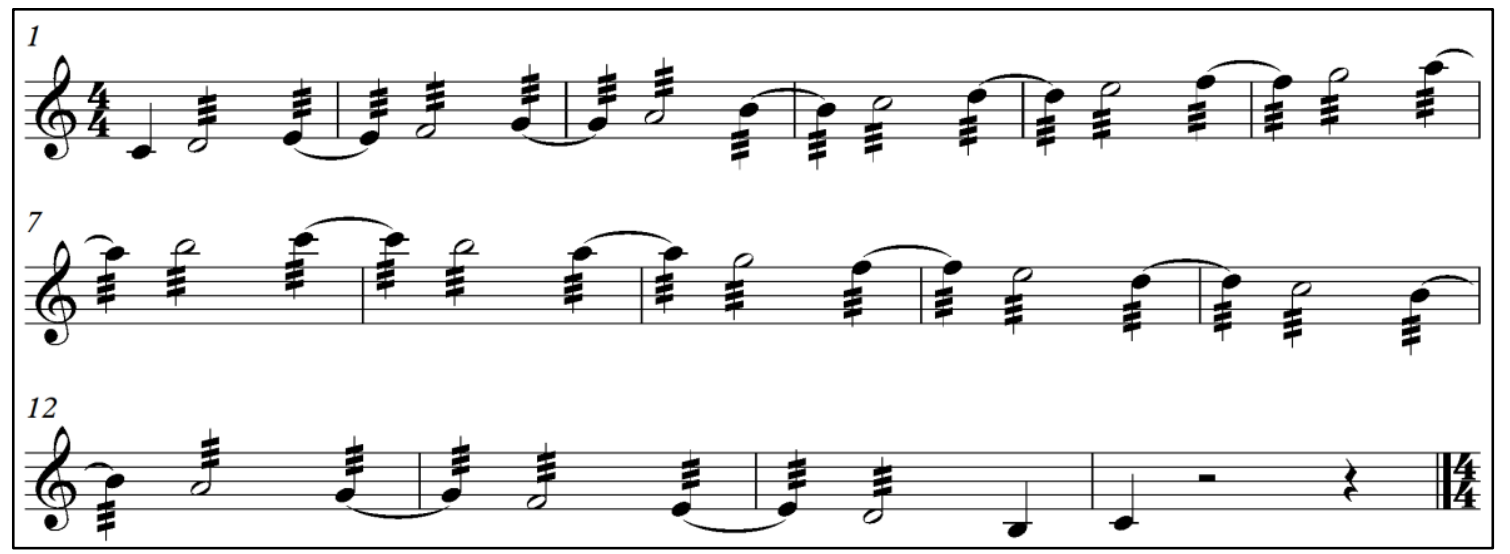

\begin{tabular}{|l|l|l|}
\hline أوافق & \\
\hline & & \\
\hline
\end{tabular}

التدربب الثالث

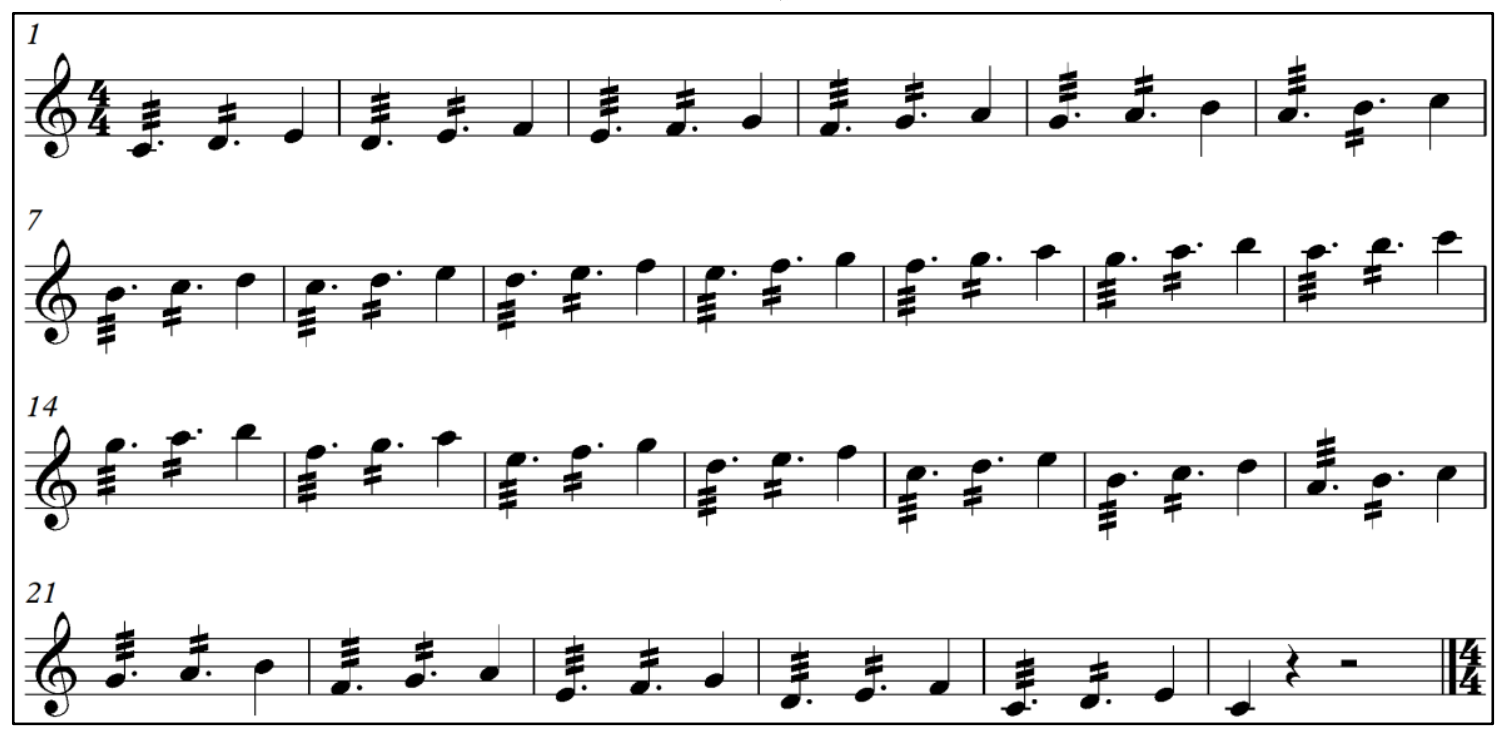

\begin{tabular}{|l|l|l|}
\hline أوافق & (أوافق \\
\hline & & \\
\hline
\end{tabular}

مجلة علوم وفنون الموسيقى - كلية التربية الموسيقية - المجلد الخامس والأربعون - يوليو ابrrم 


$$
\text { التدربب الرابع }
$$

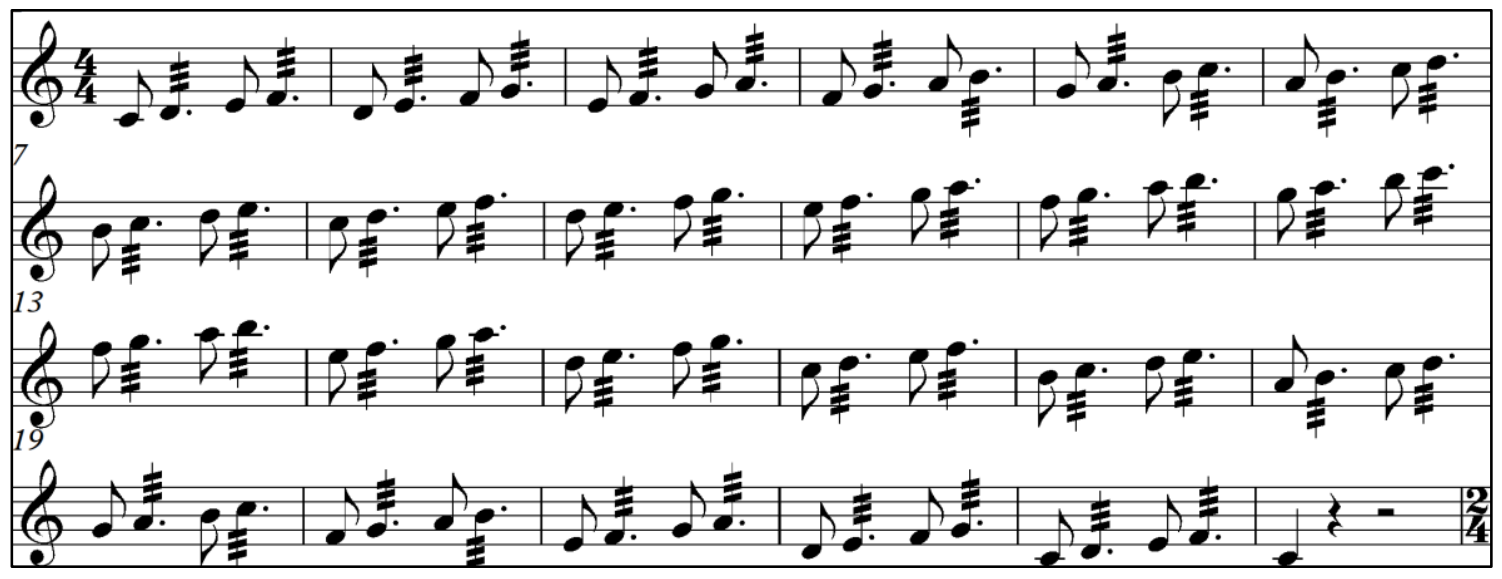

\begin{tabular}{|l|l|l|}
\hline أوافق & أوافق \\
\hline & & \\
\hline
\end{tabular}

$$
\text { التدربب الخامس }
$$

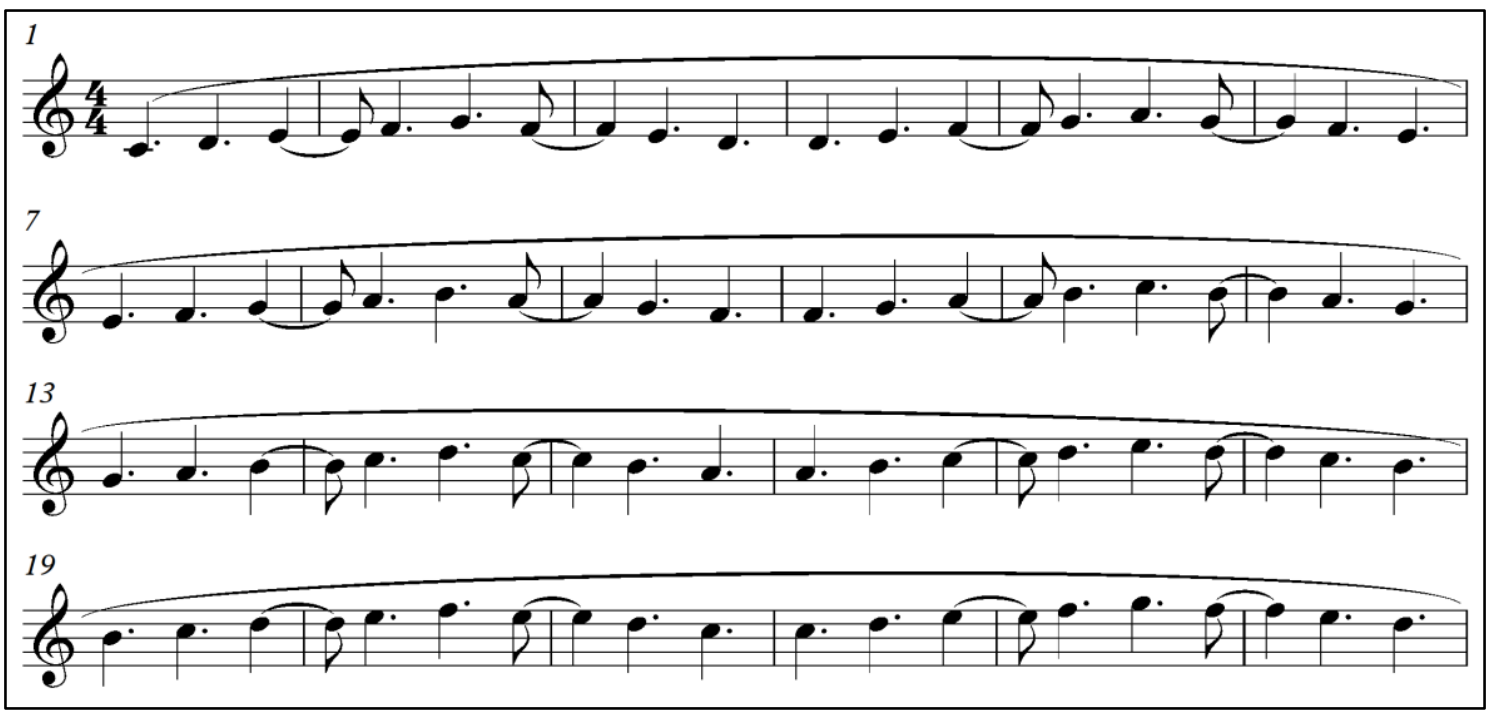

\begin{tabular}{|l|l|l|}
\hline أوافق & \\
\hline & & \\
\hline
\end{tabular}

مجلة علوم وفنون الموسيقى - كلية التربية الموسيقية - المجلد الخامس والأربعون - يوليو اب.rم 


$$
\text { التدربب السادس }
$$

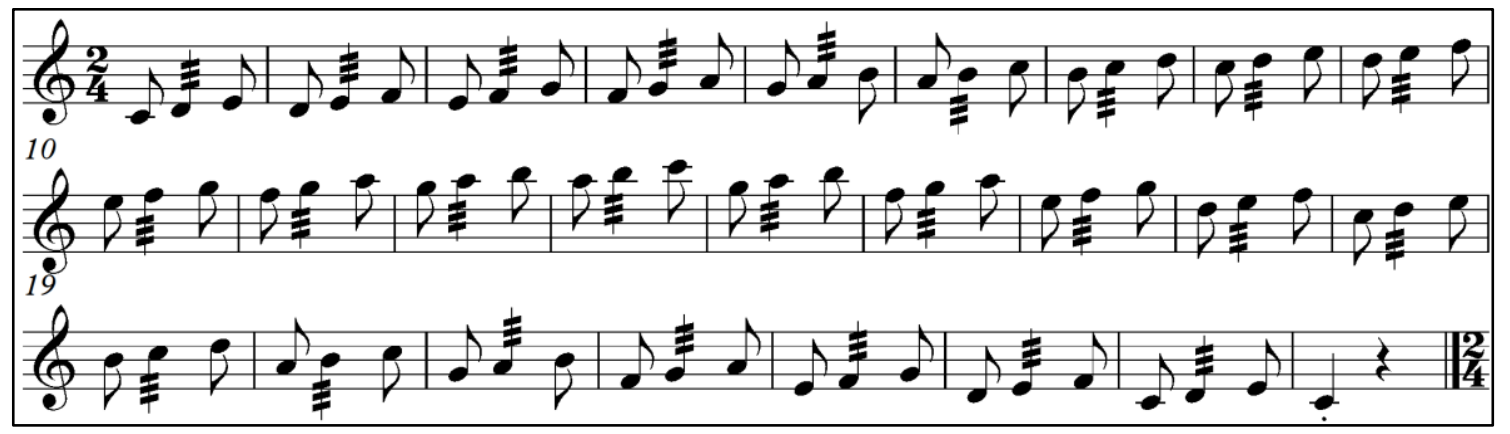

\begin{tabular}{|l|l|l|}
\hline أوافق & \\
\hline & & \\
\hline
\end{tabular}

$$
\text { التدريب السابع }
$$

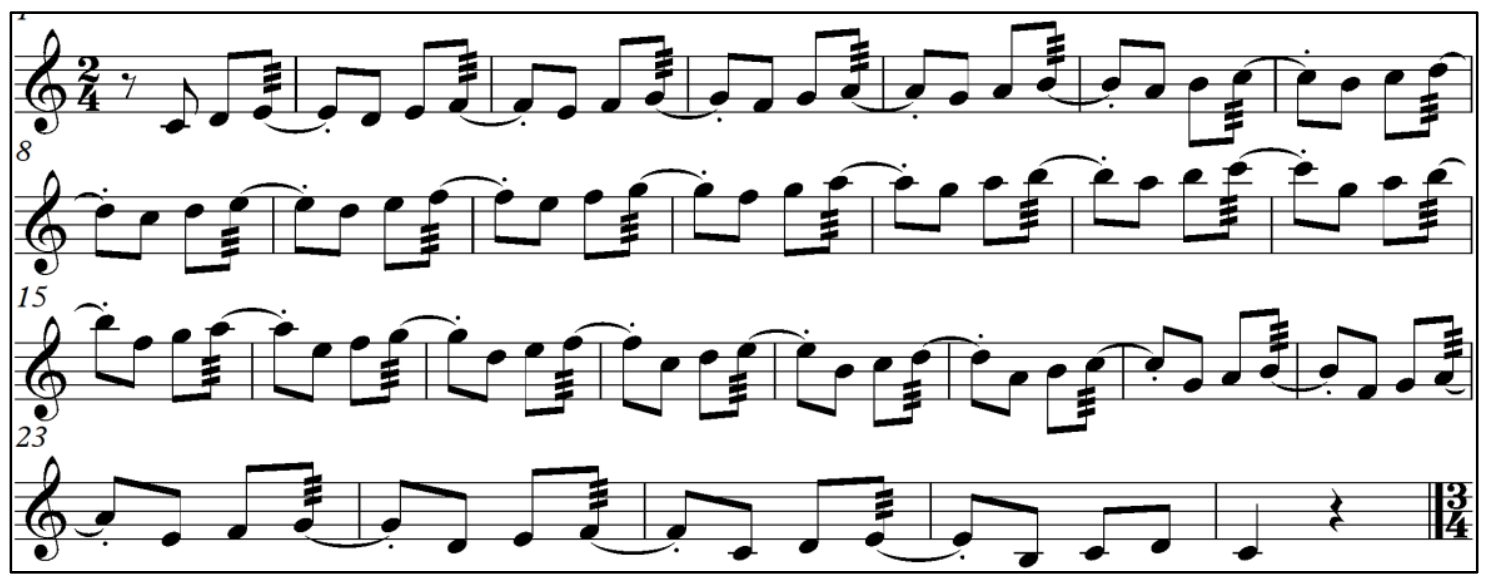

\begin{tabular}{|l|l|l|}
\hline أوافق & \\
\hline & & \\
\hline
\end{tabular}

مجلة علوم وفنون الموسيقى - كلية التربية الموسيقية - المجلد الخامس والأربعون - يوليو اب.rم 


$$
\text { التدربب الثامن }
$$

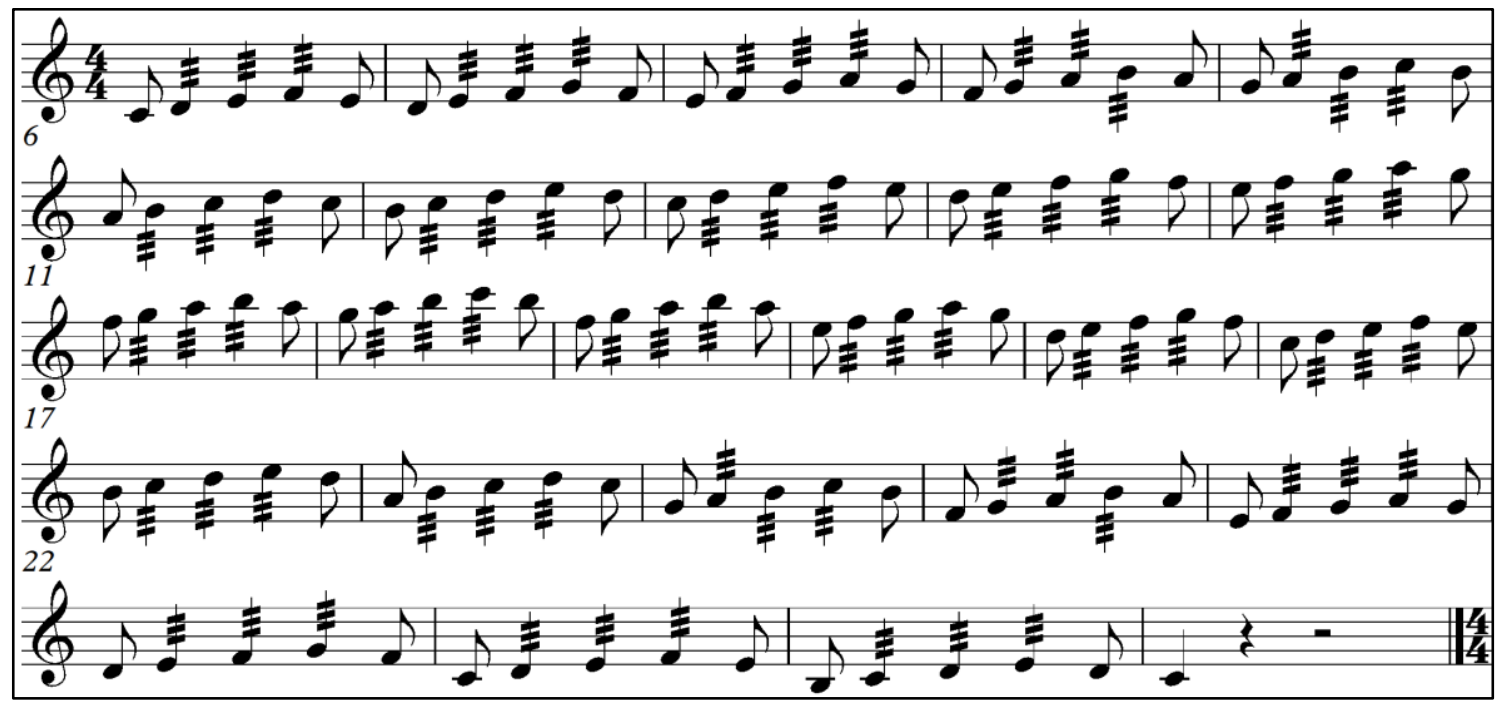

\begin{tabular}{|r|r|r|}
\hline أوافق & أوافق & \\
\hline & & \\
\hline
\end{tabular}

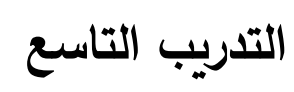

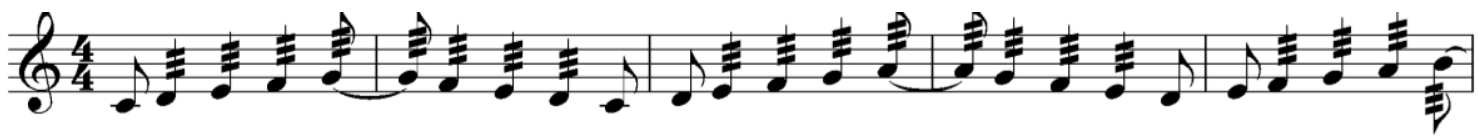

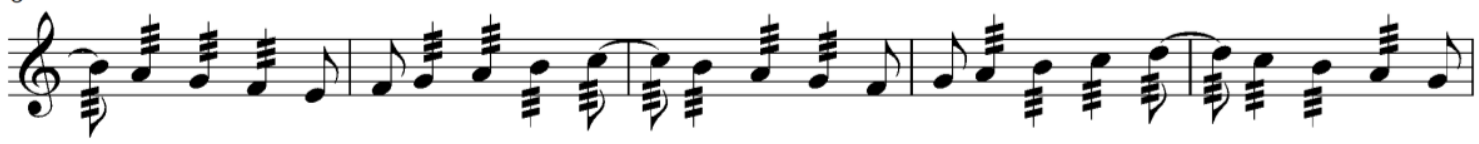

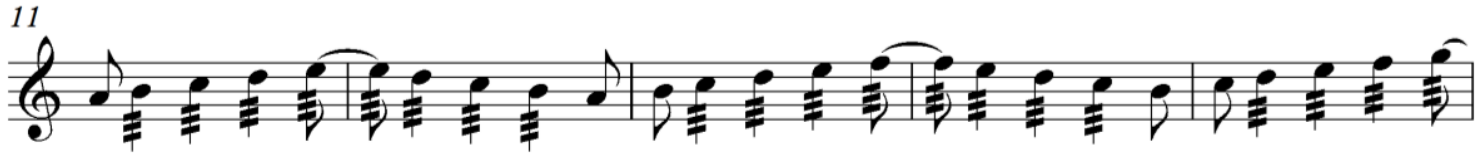

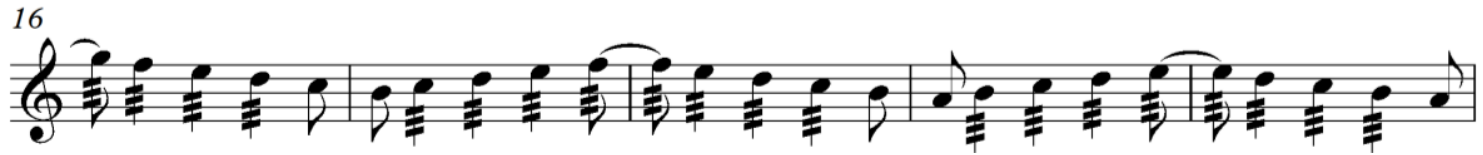

\begin{tabular}{|l|l|l|}
\hline أوافق & أوافق \\
\hline & & \\
\hline
\end{tabular}

مجلة علوم وفنون الموسيقى - كلية التربية الموسيقية - المجلد الخامس والأربعون - يوليو اب.rم 


$$
\text { التدربب العاشر }
$$

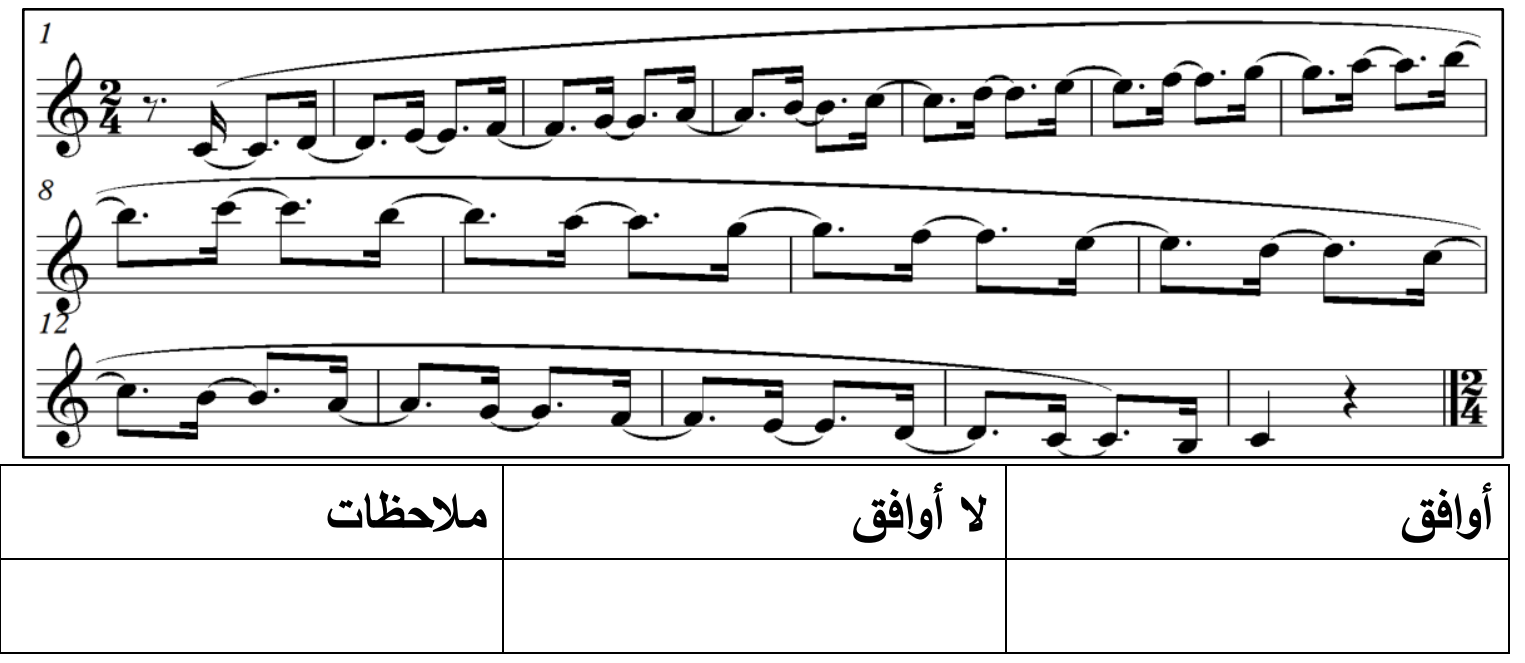

$$
\text { التدريب الحادى عثر }
$$

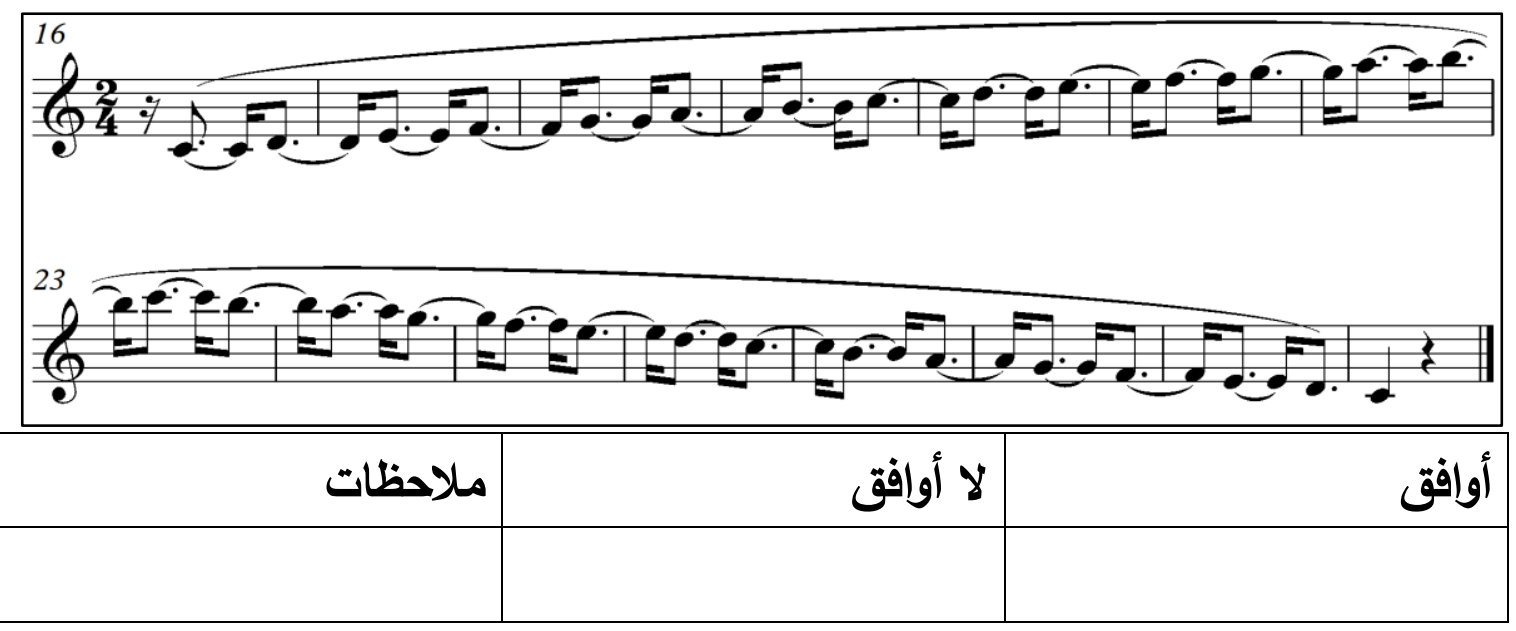

التدربب الثانى عشر

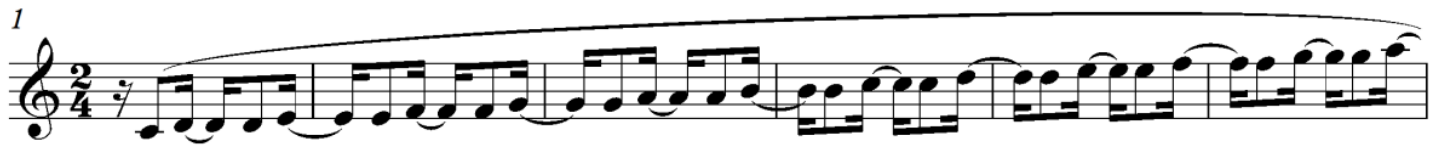

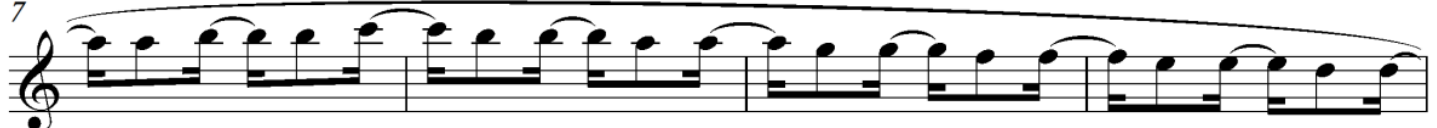

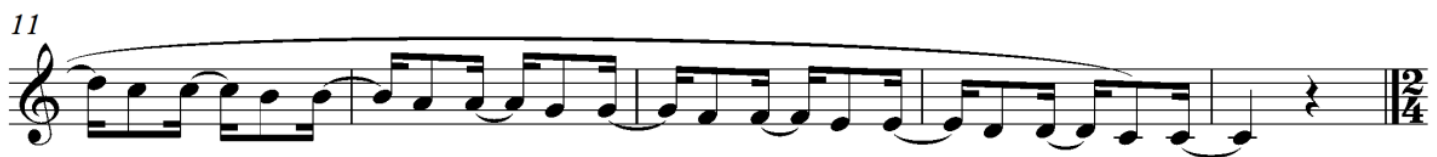
مجلة علوم وفنون الموسيقى - كلية التربية الموسيقية - المجلد الخامس والأربعوز - يوليو اب.rم 


\begin{tabular}{|r|r|r|}
\hline أوافق & (أوافق \\
\hline & & \\
\hline
\end{tabular}

التدريب الثالث عشر

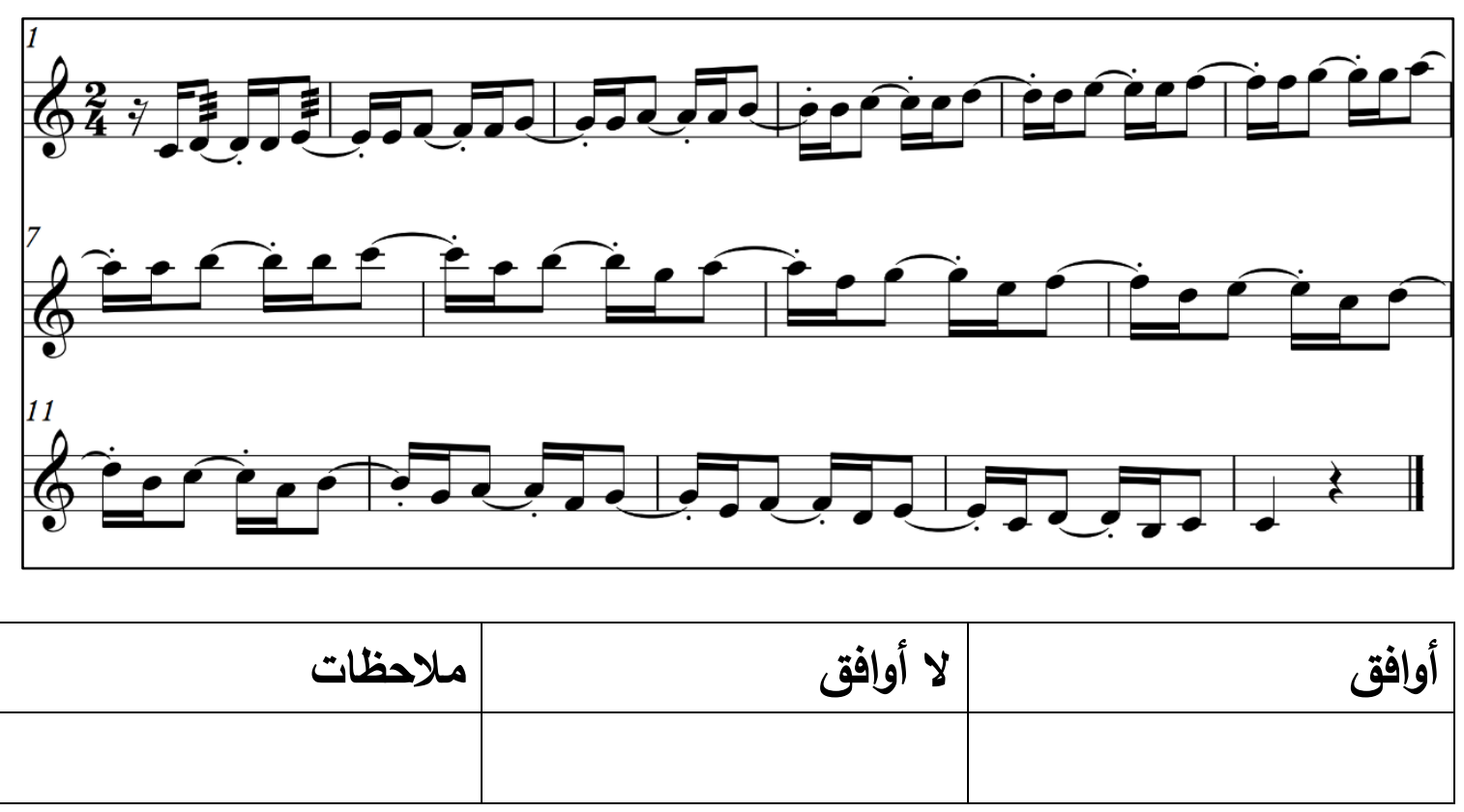

التدربب الرابع عشر

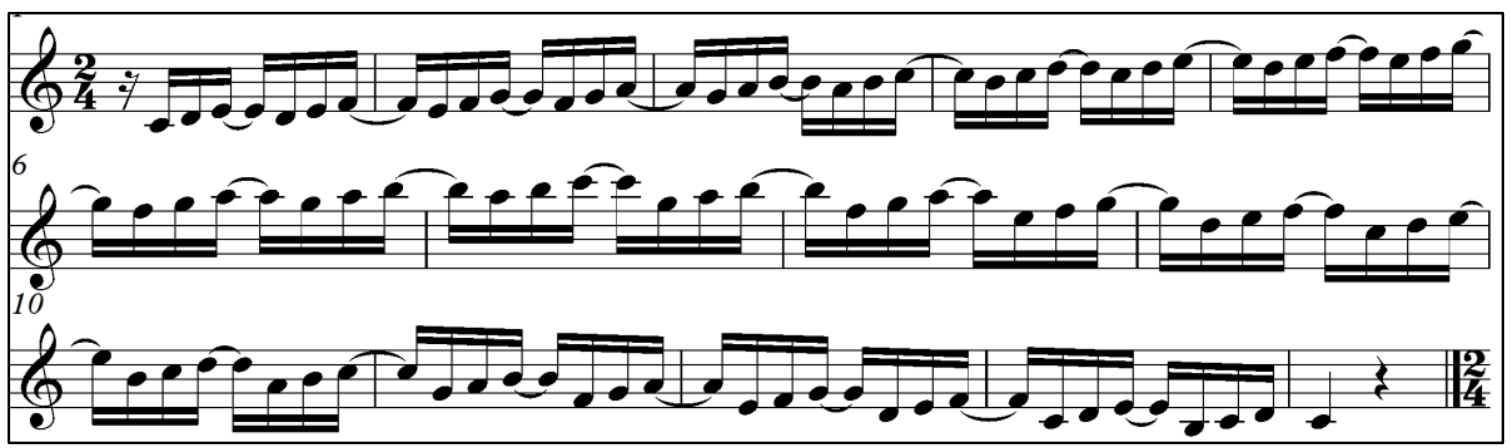

\begin{tabular}{|l|r|r|}
\hline أوافق & \\
\hline & & \\
\hline
\end{tabular}

مجلة علوم وفنون الموسيقى - كلية التربية الموسيقية - المجلد الخامس والأربعوز - يوليو اب.rم 
التدريب الخامس عثر

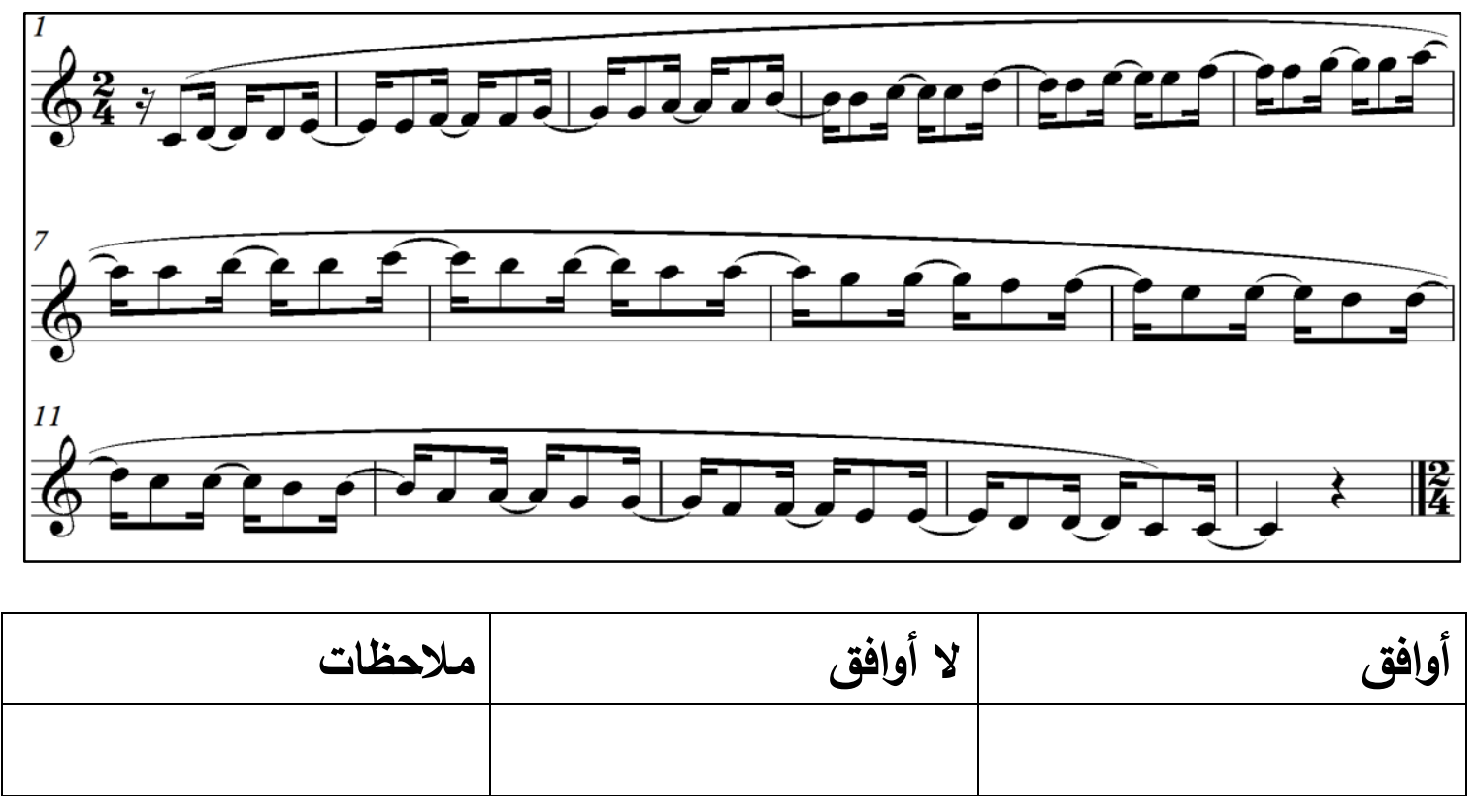

مجلة علوم وفنون الموسيقى - كلية التربية الموسيقية - المجلد الخامس والأربعون - يوليو ابr.rم 


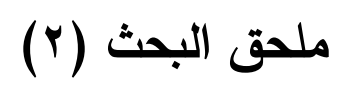

أسماء السادة الأساتذة المحكمين الذين إستعان بهم الباحث فى الإسترشاد برأبهم فى العى مدى صلاحية التدريبات المقترحة ومدى ملائمتها للهذف منها.

\begin{tabular}{|c|c|}
\hline | كلية التربية الموسيقية جامعة الموسيقى العربية & أ. أد / هلى خليفة محمد \\
\hline كلية التربية الموسيقية جامعة حلواذ المبونية التربوية & أ أد / محمد محمود عارف \\
\hline كلية التربية الموسيقية جامعة العلوم الموسيقية التربوية & أ.أد / داوود محمد سمير الجميعى \\
\hline 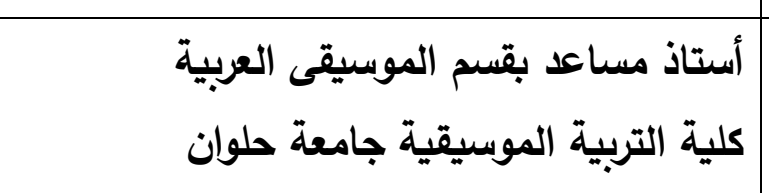 & أ.م.د / عبير طه عبد العزيز \\
\hline كلية التربية الموسيقية جامعة حلواند العومية الموسية التربوية & أ.م.د / أسامة على محمد أحمد إبراهيم \\
\hline كلية التربية النوعية جامعة عين شمبية التوسيقية & م.د / صابر عبد الستار محمود \\
\hline 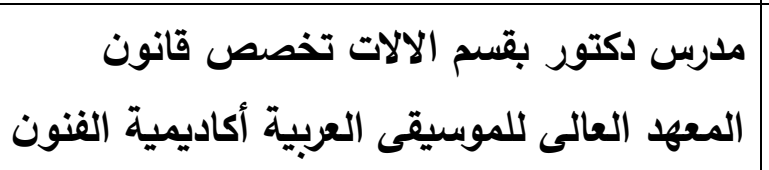 & م.د / سامر إبراهيم عبد العزيز بركات \\
\hline
\end{tabular}

مجلة علوم وفنون الموسيقى - كلية التربية الموسيقية - المجلد الخامس والأربعون - يوليو اب.rم 


\section{ملخص البحث :}

تدريبات مقترحة لتنمية مهارات أداء السينكوب "Syncope" على آلة القانون

الباحث / محمد مصطفى سيد

أ. أ.د/ أمل جمال الدين محمد عياد

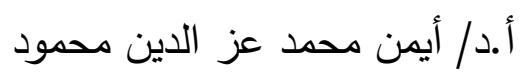

عادة يمثل أداء السينكوب صعوبة لاى الطالب نظرا لاضطراب زمن الوحدة الدنتظمة و انتقال

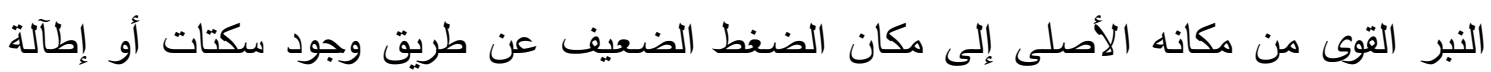
الزمن بإستخدام الرباط الزمنى حيث يتطلب الأداء الجيد إدراك كامل للإِيقاع والكثير من التنديب

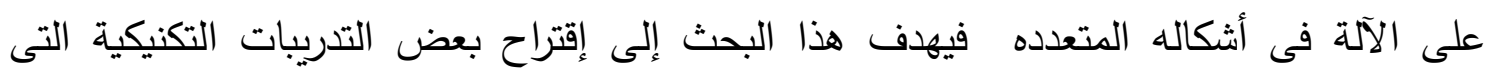

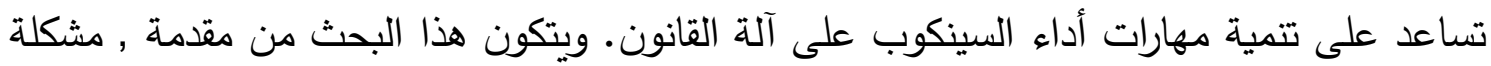

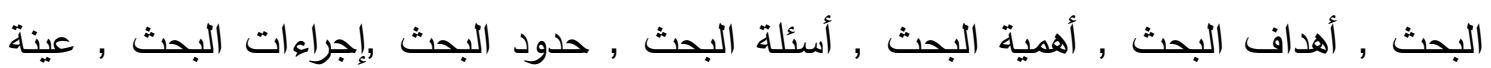

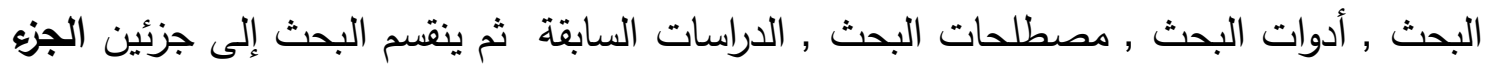
الأول: الإطار النظرى : ويثمل نبذة عن بعض مهارات أداء آلة القانون الدستخدمة فى أداء الداء

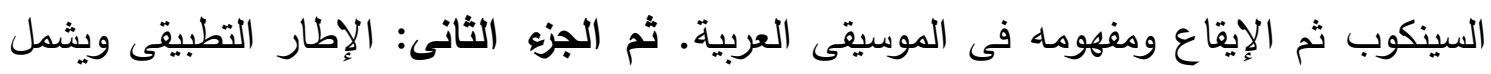
التتريبات المقترحة لبعض أشكال السينكوب الناتجة بإختلاف القيمة الزئل الزمنية لها ومعايير إعدادها.

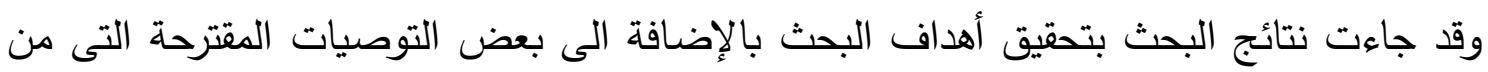

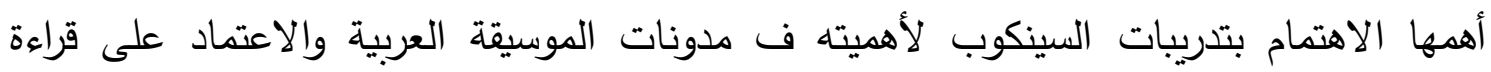

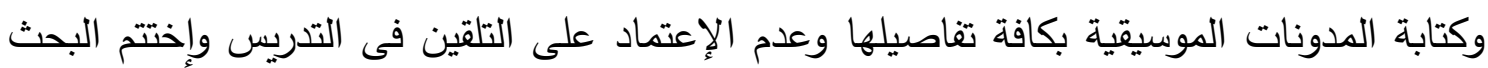

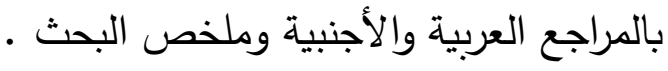




\title{
Thesis Summary:
}

\section{Suggested Exercises To Develop Skills of Syncope Performance on Qanun Instrument}

\author{
Dr. Amal Jamal El-Din Ayad Researcher: Mohamed Mostafa Sayed \\ Dr. Ayman Mohamed Ezz-El-Din Mahmoud
}

Usually, syncope performance has some difficulty because of producing expectancy violations in the listener by emphasising weak temporal locations and de-emphasising strong locations in metric structure. The good performance needs best knowledge of rhythm and more practice on the instrument in different ways. The aim of this research is to suggest some technical exercises that help to develop the skills of performing syncope on the Qanun Instrument. The study consists of an introduction, research problem, research goals, the importance of research, research questions, the limits of the research, the research procedures, a sample research, research tools, search terms and previous studies.

Then the research is divided into two parts, The first Part: theoretical framework: includes some information about the styles of performances which usually been used in Syncope, and some information about Rhythm in Arabic music Then the second part: Applied framework: includes suggested of Syncope Performances which produced by difference of its time value and how it prepared.

The results came to achieving the goals research, in addition to some of the recommendations and suggestions, the most important Is To encourage creating Syncope exercises because of its importance of Arabic Music sheets and encourage Reading and writing music sheets with all its' details and not relying on indoctrination in teaching, then research ended with Arabic and foreign references and thesis summary.

مجلة علوم وفنون الموسيقى - كلية التربية الموسيقية - المجلد الخامس والأربعون - يوليو ابr.rم 